\title{
The role of Central American barriers in shaping the evolutionary history of the northernmost glassfrog, Hyalinobatrachium fleischmanni (Anura: Centrolenidae)
}

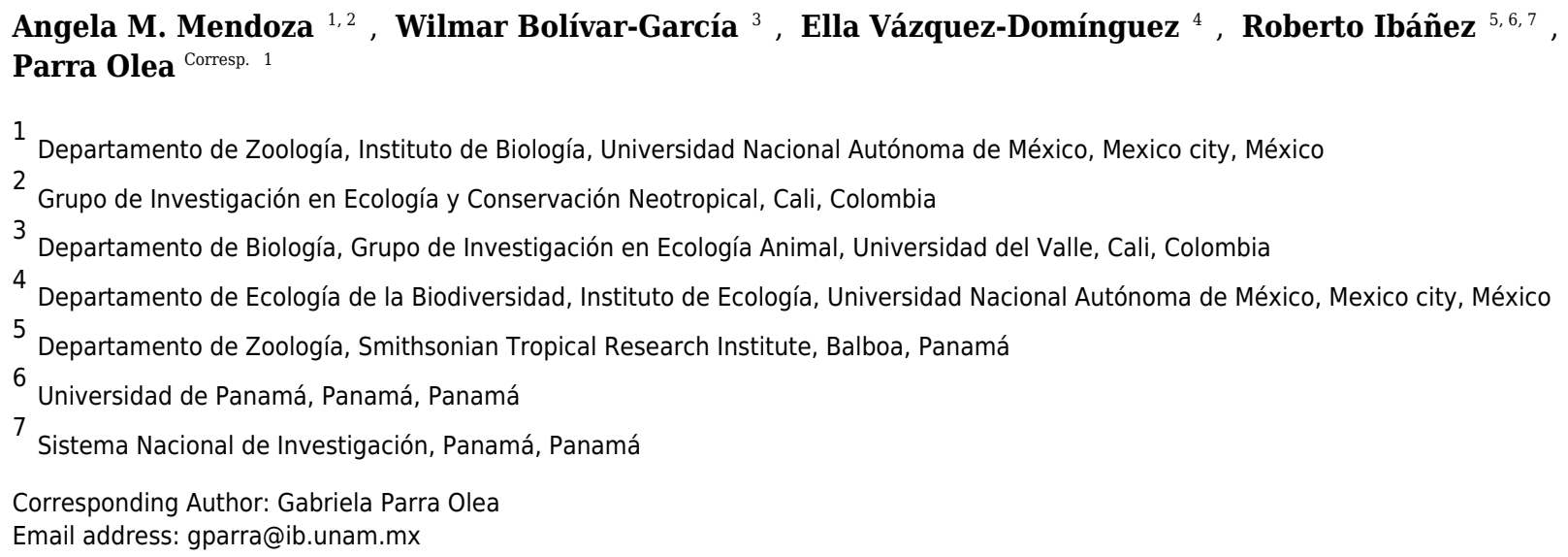

The complex geological history of Central America has been useful for understanding the processes influencing the distribution and diversity of multiple groups of organisms. Anurans are an excellent choice for such studies because they typically exhibit site fidelity and reduced movement. The objective of this work was to identify the impact of recognized geographic barriers on the genetic structure, phylogeographic patterns and divergence times of a wide-ranging amphibian species, Hyalinobatrachium fleischmanni. We amplified three mitochondrial regions, two coding (COI and ND1) and one ribosomal (16S), in samples collected from the coasts of Veracruz and Guerrero in Mexico to the humid forests of Chocó in Ecuador. We examined the biogeographic history of the species through spatial clustering analyses (Geneland and SPCA), Bayesian and maximum likelihood reconstructions, and spatiotemporal diffusion analysis. Our data suggest a Central American origin of $H$. fleischmanni and two posterior independent dispersals towards North and South American regions. The first clade comprises individuals from Colombia, Ecuador, Panama and the sister species Hyalinobatrachium tatayoi; this clade shows little structure, despite the presence of the Andes mountain range and the long distances between sampling sites. The second clade consists of individuals from Costa Rica, Nicaragua, and eastern Honduras with no apparent structure. The third clade includes individuals from western Honduras, Guatemala, and Mexico and displays deep population structure. Herein, we synthesize the impact of known geographic areas that act as barriers to glassfrog dispersal and demonstrated their effect of differentiating $H$. fleischmanni into three markedly isolated clades. The observed genetic structure is 
associated with an initial dispersal event from Central America followed by vicariance that likely occurred during the Pliocene. The southern samples are characterized by a very recent population expansion, likely related to sea-level and climatic oscillations during the Pleistocene, whereas the structure of the northern clade has probably been driven by dispersal through the Isthmus of Tehuantepec and isolation by the Motagua-Polochic-Jocotán fault system and the Mexican highlands. 
1 The role of Central American barriers in shaping the evolutionary history of the northernmost

2 glassfrog, Hyalinobatrachium fleischmanni (Anura: Centrolenidae)

3 Ángela M. Mendoza ${ }^{a, b}$, Wilmar Bolívar-García ${ }^{c}, E$ Ella Vázquez-Domínguez ${ }^{\mathrm{d}}$, Roberto Ibáñez $^{\mathrm{e}, \mathrm{f,g}}$,

4 Gabriela Parra-Olea ${ }^{\mathrm{a}, *}$

5 a Departamento de Zoología, Instituto de Biología, Universidad Nacional Autónoma de México,

6 Mexico City, Mexico.

7 b Grupo de Investigación en Ecología y Conservación Neotropical, Cali, Colombia.

$8{ }^{c}$ Universidad del Valle, Departamento de Biología, Grupo de Investigación en Ecología Animal.

9 Cali, Colombia.

$10{ }^{d}$ Departamento de Ecología de la Biodiversidad, Instituto de Ecología, Universidad Nacional

11 Autónoma de México, Mexico City, Mexico.

12 e Smithsonian Tropical Research Institute, Balboa, Panamá

$13{ }^{f}$ Departamento de Zoología, Universidad de Panamá, Ciudad de Panamá, Panamá

14 Sistema Nacional de Investigación, Panamá.

$15 *$ Corresponding author

16 Gabriela Parra-Olea

17 E-mail address: gparra@ib.unam.mx 


\section{Abstract}

Background. The complex geological history of Central America has been useful for understanding the processes influencing the distribution and diversity of multiple groups of organisms. Anurans are an excellent choice for such studies because they typically exhibit site fidelity and reduced movement. The objective of this work was to identify the impact of recognized geographic barriers on the genetic structure, phylogeographic patterns and divergence times of a wide-ranging amphibian species, Hyalinobatrachium fleischmanni.

Methods. We amplified three mitochondrial regions, two coding (COI and ND1) and one ribosomal (16S), in samples collected from the coasts of Veracruz and Guerrero in Mexico to the humid forests of Chocó in Ecuador. We examined the biogeographic history of the species through spatial clustering analyses (Geneland and sPCA), Bayesian and maximum likelihood reconstructions, and spatiotemporal diffusion analysis.

Results. Our data suggest a Central American origin of $H$. fleischmanni and two posterior independent dispersals towards North and South American regions. The first clade comprises individuals from Colombia, Ecuador, Panama and the sister species Hyalinobatrachium tatayoi; this clade shows little structure, despite the presence of the Andes mountain range and the long distances between sampling sites. The second clade consists of individuals from Costa Rica, Nicaragua, and eastern Honduras with no apparent structure. The third clade includes individuals from western Honduras, Guatemala, and Mexico and displays deep population structure.

37 Discussion. Herein, we synthesize the impact of known geographic areas that act as barriers to glassfrog dispersal and demonstrated their effect of differentiating $H$. fleischmanni into three markedly isolated clades. The observed genetic structure is associated with an initial dispersal 
40 event from Central America followed by vicariance that likely occurred during the Pliocene. The

41 southern samples are characterized by a very recent population expansion, likely related to sea-

42 level and climatic oscillations during the Pleistocene, whereas the structure of the northern clade

43 has probably been driven by dispersal through the Isthmus of Tehuantepec and isolation by the

44 Motagua-Polochic-Jocotán fault system and the Mexican highlands. 


\section{Introduction}

Historical biogeography focuses on the role of the geographic space as a driver of biological processes such as speciation, extinction, and diversification (Cox, Lalde \& Moore, 2016). Areas with a complex geological history are characterized by the appearance and disappearance of multiple barriers and corridors in their history. These barriers may significantly affect the gene flow of resident species, leading to allopatric speciation by vicariance, whereas corridors may lead to species dispersal and colonization of new areas (Noss, 1991). The use of molecular data for the reconstruction of species relationships, the development of new methods for biogeographic analyses, and the increase in geological studies in complex regions have revolutionized the understanding of such biological processes (Ronquist \& Sanmartin, 2011). Biogeographic studies have integrated information regarding the relationships within or between closely related taxa, providing valuable opportunities to understand how patterns of biodiversity may have been shaped, even at short time scales (Crawford, Bermingham \& Polanía-S, 2007; Streicher et al., 2014).

Central America is a region with a rather complex biogeographic history and high diversity of habitats and species (Myers et al., 2000; Cavers, Navarro \& Lowe, 2003; Iturralde-Vinent, 2006; Daza, Castoe \& Parkinson, 2010). The region is delimited to the north by the Isthmus of Tehuantepec (IT) in Mexico and to the south by the Andes in Colombia (Gutiérrez-García \& Vázquez-Domínguez, 2012). The geological landscape of Central America has been continuously modified, especially during the last 15 million years (Ma), by major events including the emergence of the Panama Arc (13-15 Ma, Montes et al., 2015), the posterior closure of the Panama Isthmian land bridge when it ceased to function as a seaway ( 9-10 Ma, Montes et al., 2012a; Montes et al., 2012b; Ramirez et al., 2016), and the posterior global 
69 climatic transitions during the Plio-Pleistocene (Montes et al., 2015). These events triggered the

70 Great American Biotic Interchange, or GABI, involving the replacement of native taxa

71 (extinctions) and the establishment and diversification of colonizing taxa (speciation) on both

72 continents (Marshall et al., 1982; Stehli \& Webb, 1985). Ample phylogeographic research in this

73 region has allowed the effects of geomorphology, topographic barriers, volcanic activity, large

74 climate changes, intermittent connections, and corridors on the biota to be described, aiding in

75 our understanding of the influence of past events on the patterns of genetic structure and the geographic distribution of birds (García-Moreno et al., 2004; Cadena, Klicka \& Ricklefs, 2007;

77 Arbeláez-Cortés, Nyári \& Navarro-Sigüenza, 2010), plants (Cavers, Navarro \& Lowe, 2003;

Ornelas, Ruiz-Sánchez \& Sosa, 2010; Cavender-Bares et al., 2011), reptiles (Hasbún et al., 2005;

79 Venegas-Anaya et al., 2008), mammals (Eizirik et al., 2001; Ordoñez-Garza et al., 2010; Pérez-

80 Consuegra \& Vázquez-Domínguez, 2017), and amphibians (Mulcahy, Morrill \& Mendelson,

81 2006; Crawford, Bermingham \& Polanía-S, 2007; Wang, Crawford \& Bermingham, 2008;

82 Hauswaldt et al., 2011). As a result, diverse geological factors and major barriers have been

83 more frequently correlated with the evolutionary history and dispersal of species (Bagley \&

84 Johnson, 2014).

85 Amphibians are excellent systems for studies in which geological and environmental histories are inferred at fine scales, due to their ecology, particularly regarding their terrestrial habits,

87 intolerance to salt water (Beebee, 2005), and marked niche conservatism (Smith, Stephens \&

88 Wiens, 2005; Wiens et al., 2006), as well as the restriction of the particular habitats of many

89 species (e.g., Savage, 2002). However, evaluation of the impact of barriers on the

90 phylogeographic patterns of this taxon, extending across the entire Central American region, has

91 been precluded because most amphibians have small ranges. 
92 Glassfrogs (Centrolenidae) comprise a diverse family endemic to the Neotropics, with numerous

93 species and high levels of endemism, mainly distributed among the Northern Andes and Central

94 America regions (Guayasamin et al., 2009; Castroviejo-Fisher et al., 2014; Mendoza \& Arita,

95 2014). Studies on the dispersal capability of glassfrogs are limited, but these frogs are known to

96 be restricted to streamside habitats (Ruiz-Carranza \& Lynch, 1991) and to show site fidelity

97 (Valencia-Aguilar, Castro-Herrera \& Ramírez-Pinilla, 2012) and low mobility, with potential

98 genetic subdivision and restricted gene flow (Delia, Bravo-Valencia \& McDiarmid, 2017;

99 Robertson, Lips \& Heist, 2008). The glassfrog Hyalinobatrachium fleischmanni (Boettger, 1893)

100 has one of the widest distributions, ranging from Guerrero and Veracruz states in Mexico

101 through the lowlands of Central America, to the southernmost limit of its distribution in Ecuador

102 (Cruz et al., 2017). Males of the species call from vegetation along the margins of streams, and

103 egg masses are usually laid on the underside of leaves over a stream. This species exhibits site

104 fidelity and parental care by males, who attend one or more clutches at the same time (Delia et

105 al., 2010; Savage, 2002; Barrera-Rodríguez, 2000). Tadpoles fall from vegetation into the water,

106 where they develop; they are apparently fossorial, living buried in the leaf litter and bank

107 substrate of streams (Villa \& Valerio, 1982). Related species (i.e. Hyalinobatrachium tatayoi, $H$.

108 carlesvilai, H. mondolfii, H. kawense, and H. munozorum) are distributed in different regions of

109 South America, including the northern and central Andes, Guiana shield, and Amazon basin,

110 where previous analyses have suggested an Andean origin for H. fleischmanni (Castroviejo-

111 Fisher et al., 2014).

112 Considering its wide distribution, coupled with its site fidelity, H. fleischmanni is an ideal

113 organism for studying the role that Central American geographic barriers have played in the

114 dispersal patterns of lowland glassfrog species. In the present study, we had the following 
115 objectives: (1) to reconstruct the historical biogeography that has shaped the evolutionary history

116 of H. fleischmanni, including dispersal or vicariance events and time of divergence; (2) to

117 evaluate the possible presence of multiple isolated lineages within H. fleischmanni; and (3) to

118 identify the impact of recognized geographic barriers on the genetic structure and

119 phylogeographic patterns of $H$. fleischmanni over time. Based on known information about the

120 species, we tested the hypothesis that H. fleischmanni had a South American origin and

121 subsequently dispersed into the Central American lowlands after the closure of the Isthmus of

122 Panama. Additionally, we hypothesized that the dispersal of this species in Central America has

123 been limited by various high mountain ranges acting as barriers and that changes in sea level

124 during the Pleistocene had an impact on the genetic structure of the lowland populations (Bagley

125 \& Johnson 2014). Hence, our prediction is that the current genetic structure of $H$. fleischmanni

126 reflects patterns of vicariance events driven by dispersal barriers.

\section{Materials and methods}

Tissue sampling

129 Genetic material was obtained across the entire distribution area of the species, from both

130 museum collections and fieldwork (Fig. 1). Fieldwork was performed during the rainy season, in

131 which at least three individuals were collected at each locality. Specimen collection permits were

132 provided by the Ministerio de Medio Ambiente, Colombia (Resolution 120 of 24 August 2015)

133 and the Secretaría del Medio Ambiente y Recursos Naturales, Mexico (office number 00947/16).

134 Captured specimens were euthanized with a 20\% lidocaine hydrochloride (Xylocaine) injection,

135 and all efforts were made to minimize suffering. Liver or muscle tissues were collected in the

136 field and were stored in an RNAlater solution until their use in the laboratory. Specimens were 
137 fixed with 10\% formalin, stored in 70\% ethanol and deposited in biodiversity collections at

138 public research institutions in each country.

139 Molecular techniques

140 DNA was obtained from muscle and liver tissues following the phenol-chloroform extraction

141 protocol (Sambrook \& Russell, 2006). The quantity and quality of the DNA were verified in $1 \%$

142 agarose gels and by measuring absorbance using a NanoDrop spectrometer (Thermo Fisher

143 Scientific Inc., Wilmington, DE, USA). Amplification of the mitochondrial COI (658 bp), 16S

144 (895 bp), and ND1 (961 bp) genes was performed following the protocols described by

145 Guayasamin et al., (2008). PCR products were visualized with agarose gels and purified

146 according to the EXO-SAP protocol (GE Healthcare, Piscataway, NJ, USA). DNA sequences

147 were obtained with the BigDye Terminator Cycle Sequencing kit (Applied Biosystems).

148 Sequences from H. tatayoi from Venezuela (Guayasamin et al., 2008; Castroviejo-Fisher et al.,

149 2007) were also included. The sequences were assembled, manually edited and aligned with

150 Geneious 9.1.2., and the three genes were concatenated by using the cbind function in the ape

151 package in R (Paradis, Claude, \& Strimmer, 2004).

152 We are aware that analyses based on mitochondrial DNA (mtDNA) provide a limited view of 153 species evolution (i.e., matrilineal inheritance), but the available genetic material from nuclear

154 Central America is very scarce since there has been limited or no sampling in the region (due to a

155 lack of funding as well as logistical and even bureaucratic difficulties) compared to that in

156 northern or southern countries. Therefore, we chose to compile a database including gene

157 sequences available from GenBank and BOLD databases with our own sequences to perform our 
158 analyses. In this way, our study encompasses the entire geographic distribution of $H$.

159 fleischmanni, allowing us to evaluate the events shaping the evolutionary history of the species.

160 Additionally, mtDNA is a robust indicator of population structure and historical biogeographic

161 barriers and can be used to detect cryptic diversity (Gehara et al., 2014; Duoit et. al., 2018; Lait

162 \& Hebert, 2018). Mitochondrial DNA markers have been used in a variety of Central American

163 studies to decipher genetic structuring (for a review, see Bagley \& Johnson 2014), allowing us to

164 make direct comparisons with previous studies from this region.

165 Data analysis

166 Identification of landscape barriers to dispersal

167 We defined a priori a set of possible geographic elements based on the four geological blocks

168 across Central America (Maya, Chortis, Chorotega, and Chocó) (Marshall, 2007; Gutiérrez-

169 García \& Vázquez-Domínguez, 2012) as well as their northern and southern limits: the southern

170 Mexico Block (SMB) west of the IT and the South American Plate (SAP) east of the Andes,

171 respectively. The effects on species dispersal were evaluated for three highland barriers: the

172 Motagua-Polochic-Jocotán (MPJ) fault system, the Talamanca Cordillera, and the Andes range,

173 which separates the Northern Andes (Western and Central Cordilleras) and the Eastern

174 Cordillera (including Serranía del Perijá). Three previously recognized barriers for lowland

175 amphibians (the Hess Escarpment, HE; western Panama Isthmus, WPI; and central Panama

176 Isthmus, CPI) were also tested as possible factors during Pleistocene sea-level oscillations (Fig.

177 1). Each barrier was tested by four spatial and non-spatial analyses, and supported barriers were

178 defined as those detected by at least three of the analyses. 
179 The first step was to perform spatial and clustering analyses that are commonly applied to

180 mtDNA sequences. The spatial locations of genetic discontinuities were estimated with Geneland

181 (Guillot, Mortier \& Estoup, 2005), which estimates the number of populations within the

182 geographical area of interest, maps borders between populations, assigns individuals to

183 populations, and detects possible migrants. We ran the model in $\mathrm{R}$ under the correlated allele

184 frequency model, without uncertainty regarding spatial locations. We generated $10^{5}$ iterations to

185 a thinning of 100, with the maximum rate of the Poisson process fixed as the number of

186 individuals, and the generated map borders were compared with our hypothesized barriers.

187 Additionally, we performed a spatial principal component analysis (sPCA; Jombart, 2008a)

188 using the adegenet package in R (Jombart, 2008b) for which we constructed a neighbor-distance

189 net among all coordinates and tested for significant, geographically correlated genetic structures

190 along the main axis based on a global randomization test. We extracted the values of the first two

191 sPCA components and generated polygons for each interbarrier set of individuals to test if the

192 populations adjacent to each barrier were clustered (non-overlap) or displayed as a continuum

193 (partially or completely overlapping). Previous studies have suggested multivariate ordination

194 analyses as an alternative to Bayesian algorithms because they do not make any assumptions

195 about the underlying population genetic model (Jombart, Devillard \& Balloux, 2010).

196 Additionally, we performed a non-spatial test by estimating the Nei's pairwise $F_{S T}$ value between

197 adjacent regions and estimated significance by a Monte Carlo test based on 999 permutations

198 with the hierfstat package (Goudet \& Jombart, 2015); because we did not have data for the three

199 mitochondrial genes for all samples in all localities, these analyses included missing values.

200 Additionally, we used the alignments per gene to calculate diversity indices and to perform 
201 additional clustering analyses that do not support missing values in the concatenated sequences

202 (see Supplementary Material).

203 Phylogenetic analyses

204 Since phylogeographic breaks can be detected in the form of phylogenetic splits between mostly

205 distinct geographical lineages (Bagley \& Johnson, 2014), the sequences of all genes were

206 concatenated, and a phylogenetic tree was estimated at the intraspecific level by implementing

207 both likelihood analysis in RAxML (Stamatakis, 2006) and a Bayesian inference approach in

208 MrBayes (Ronquist \& Huelsenbeck, 2003). We rooted our phylogeny using the species

209 Hyalinobatrachium carlesvilai, H. mondolfii, H. chirripoi and H. colymbiphyllum as outgroups.

210 A list of the specimens and GenBank accession numbers included in this study is presented in

211 Table S1. The best evolutionary model for each noncoding region (16S) and for the coding genes

212 (COI and ND1) was evaluated using PartitionFinder 2 software (Lanfear et al., 2016). Maximum

213 likelihood analysis was conducted using 10,000 rapid bootstrap analyses, the GTR $+\Gamma$ evolution

214 model and summarized support for the best tree. For Bayesian inference, we ran two independent

215 analyses for 12 million generations, sampling trees and parameter values every 1,000

216 generations. Burn-in was set to $25 \%$, and the first 3 million generations were therefore discarded.

217 Divergence times and Bayesian spatiotemporal diffusion analyses

218 To estimate diversification times for the different $H$. fleischmanni mitochondrial lineages, we

219 employed BEAST 1.6.2 (Drummond \& Rambaut, 2007). The time to the most recent common

220 ancestor (MRCA) for the main lineages was calculated via Bayesian Markov chain Monte Carlo

221 (MCMC) searches. The ultrametric tree was inferred de novo using the same partition

222 substitution models. In the absence of a fossil record for glassfrogs, we based our analysis on 
223 previously published divergence times. We used three stem ages for Hyalinobatrachium species

224 as calibration constraints, following Castroviejo-Fisher et al. (2014). The most recent calibration

225 point was placed at $2.42 \mathrm{Ma}$ (confidence interval $(\mathrm{CI})=1.63-3.37)$, representing the divergence

226 between $H$. fleischmanni (USNM 559092) and H. tatayoi (MHNLS 17174). The following

227 calibration node was placed at 7.65 $\mathrm{Ma}(\mathrm{CI}=5.93-9.63)$, representing the divergence between

228 H. fleischmanni-H. tatayoi and H. carlesvilai, and the most ancient calibration point

229 corresponded to the divergence between $H$. fleischmanni and H. mondolfii $(8.4 \mathrm{Ma}, \mathrm{CI}=6.68-$

230 10.52). The calibration points on inner nodes in Castroviejo-Fisher et al. (2014) were based on a

231 geological vicariance-based strategy, which requires additional precautions (Kodandaramaiah,

232 2011) when compared to the fossil-based calibration approach. For more detail, see the section

233 on divergence time estimates and Appendix S1 in Castroviejo-Fisher et al. (2014). We

234 implemented an uncorrelated lognormal relaxed molecular clock, and trees were sampled every

2351,000 th iteration for $100,000,000$ generations, with $20 \%$ of the initial samples being discarded as

236 burn-in, after empirical assessment of appropriate chain convergence and mixing with Tracer 1.7

237 (Rambaut et al., 2018). We constructed the historical demography of the major clades obtained

238 from the phylogenetic results, using Bayesian skyline plots that estimate the posterior

239 distribution of population sizes (Drummond et al., 2005).

240 To reconstruct the ancestral distribution and spatial dispersal of the species, we performed a

241 Bayesian spatiotemporal diffusion analysis in BEAST (v.1.8.4), assuming continuous spatial

242 diffusion with a time-heterogeneous random walk model ("Relaxed Random Walk", RRW,

243 Lemey et al., 2010). For this analysis, we used a subset of 34 samples with data for all three

244 genes plus samples lacking some genes but originating from intermediate localities,

245 encompassing the entire distribution of the species. We applied a normally distributed diffusion 
246 rate, a coalescent Bayesian Skyride model, and SRD06 substitution models (Shapiro, Rambaut \&

247 Drummond, 2005). We used the jitter option under the TraitLikelihood statistic with a parameter

248 value of 0.1 . To summarize the posterior distribution of ancestral ranges using the RRW model,

249 we annotated nodes in a maximum clade credibility tree (MCC) using the program

250 TreeAnnotator v1.7.5. This tree was then used as an input in SpreaD3 (Bielejec et al., 2016) to

251 reconstruct the pattern of spatial diffusion and to visualize lineage diversification across the

252 landscape. If $H$. fleischmanni had a South American origin and subsequently dispersed to Central

253 America after the closure of the Isthmus of Panama as we hypothesized, we would expect that

254 the MRCA of all H. fleischmanni would be located in South America, and the more recent nodes

255 would represent dispersal events into North America.

\section{Results}

257 We generated a final alignment of 2036 base pairs (bp) for 123 samples from 9 countries,

258 including 13 sequences obtained from the GenBank and BOLD system databases (Table S1).

259 The obtained sequences, representing unique haplotypes of the single genes, are available via

260 GenBank (accession numbers: MG944443-MG944695). We did not detect any stop codons in

261 protein-coding genes (COI, ND1). We obtained 25 haplotypes with an overall haplotypic

262 diversity $(h)=0.863$ and a nucleotide diversity $(\pi)=1.282$ for the $16 \mathrm{~S}$ gene. In contrast, we

263 found 63 haplotypes for COI, with $h=0.979$ and $\pi=0.044$, and 45 haplotypes for ND1, with $h=$

2640.991 and $\pi=0.042$ (Table S1.2).

265 Spatial clustering analysis.

266 The Nei's pairwise $F_{S T}$ results showed significant differences between adjacent regions for all

267 barriers except for the HE and the Eastern Cordillera (Table 1). The Geneland map of population 
268 membership for the concatenated genes revealed nine clusters that partially coincided with our

269 hypothesized barriers, depicting the IT, the MPJ fault system, the Talamanca Range and the WPI

270 as barriers. Additionally, three non-considered barriers were indicated between samples from

271 west of the IT and on the Chortis block, between samples from both sides of the Darien and

272 between the Ecuadorian and Colombian samples (Fig. 2a).

273 sPCA performed on individual genotypes revealed a significant, geographically correlated

274 genetic structure for all three genes (nper $=999, P=0.001)$. Eigenvalues indicated a higher

275 spatial genetic structure for the main axis, related to the global structure. The positive axis of the

276 first sPCA (regional scale) exhibited the greatest variation in genetic distance in relation to the

277 distance network (Fig. 2b). The samples separated by the WPI, the Talamanca Range and the

278 MPJ fault system did not overlap based on the two sPCA first components, while the samples

279 separating the IT and HE exhibited partial overlap (Fig. 2c).

280

281

282

283

284

285

286

287

288

Phylogenetic patterns, times of divergence, and demography

The PartitionFinder output indicated that $\mathrm{HKY}+\mathrm{I}+\mathrm{G}, \mathrm{GTR}+\mathrm{G}$, and $\mathrm{GTR}+\mathrm{G}+\mathrm{I}$ were the best models for 16S, COI, and ND1 respectively. The phylogenetic relationships based on the Bayesian and maximum likelihood approaches for the concatenated genes indicated three main, well-supported clades, although their relative positions were not fully resolved (Fig. 3). The first clade, designated the "Northern clade", was divided into two lineages: a large lineage containing all samples from the SMB and Maya regions $(\mathrm{pp}=1)$ and a smaller one from the western Chortis region $(\mathrm{pp}=1)$. The second clade, the "Central clade", was comprised of samples from the eastern Chortis and Chorotega regions $(\mathrm{pp}=1)$. The third clade, the "Southern clade", consisted of 
289 samples from the Chocó and SAP regions, including the species $H$. tatayoi from Venezuela ( $\mathrm{pp}=$

290 1). The Southern clade did not show any structure, displaying a polytomic topology.

291 The divergence time estimation results showed a pattern of divergence among the three main

292 clades occurring during the Pliocene ( 3.40 Ma, HPD = 2.25-4.56 Ma; Fig. 3). With respect to

293 the Northern clade, the split between the lineage from West Chortis and the remaining samples

294 also occurred during the Pleistocene in the Gelasian age $(\sim 2.19 \mathrm{Ma}, \mathrm{HPD}=1.38-3.53)$, while

295 separation between samples from the Pacific and Gulf + Maya regions occurred at the beginning

296 of the Calabrian age $(\sim 1.76 \mathrm{Ma}, \mathrm{HPD}=0.86-2.23)$. Finally, the split between lineages from the

297 Gulf and Maya regions occurred near the end of the Calabrian age $(\sim 1.51 \mathrm{Ma}, \mathrm{HPD}=0.62-$

298 1.73). The divergence between the Central and Southern clades occurred at the end of the

299 Pliocene ( 2.64 Ma, HPD = 1.50-3.68), while splits within each clade began at the end of the

300 Calabrian age for the Central clade $(\sim 0.81 \mathrm{Ma}, \mathrm{HPD}=0.12-0.71)$ and during the Gelasian age

$301(\sim 1.64 \mathrm{Ma}, \mathrm{HPD}=0.63-1.89)$ for the Southern clade (Fig. 3).

302 The $95 \%$ CIs of the effective population size (BSP results) overlapped along the entire time

303 period in the Northern clade (Fig. 4a). However, the ancient and recent effective population sizes

304 of the Southern clade did not overlap (by 95\% CI of the Bayesian posterior probability),

305 providing significant support for a change in population size and suggesting that the clade

306 exhibited a constant population size and posterior expansion at approximately $0.1-0.3 \mathrm{Ma}$ (Fig.

$3074 b)$.

308 The results regarding Bayesian spatiotemporal diffusion (Fig. 5) highlight the Chorotega and

309 West Chortis region as the most likely ancestral geographic area for $H$. fleischmanni, suggesting

310 two subsequent dispersal events, in which the MRCA of the Northern clade was distributed in 
311 the environs of the Chortis and Maya regions, whereas that of the Southern clade (stem node)

312 was distributed around the Chorotega and Chocó regions. Our results also reflect independent

313 dispersal for samples west of the MPJ fault system and later divergence of the three remaining

314 clusters in the Northern clade around the IT. For the Central clade, an initial range in the

315 Chorotega region south of the Talamanca range was observed, with posterior dispersal towards

316 eastern Chortis. Furthermore, an ancestral range was detected in the Chocó block within the

317 Southern clade with subsequent dispersal towards the south and east, reaching the lowlands east

318 of the Andes range to the south, while two lineages dispersed northwards independently,

319 reaching the southern limit of the Chocó region.

320 Genetic diversity and structure

321 Our results provide evidence of four of the hypothesized barriers (WPI, Talamanca Range, MPJ

322 fault system and IT) and identified two additional barriers: one east of the IT and one within the

323 Chortis block. Hence, we identified seven genetically homogeneous regions: North American

324 Pacific, Gulf of Mexico, Maya block, western Chortis, eastern Chortis-South Talamanca Range,

325 North Talamanca Range and Chocó-SAP. A minimum genetic distance (Table 2) was exhibited

326 between regions for North Talamanca Range and Chocó-SAP $(\mathrm{K} 2 \mathrm{P}=1.6 \%)$, while the

327 maximum was observed between eastern Chortis and North Talamanca Range $(\mathrm{K} 2 \mathrm{P}=6.0 \%)$.

328 Significant Nei's $F_{S T}$ indices between regions were obtained for almost all combinations $\left(F_{S T}>\right.$

329 0.4), except between North Talamanca Range and Chocó-SAP (Table 2).

330 Discussion

331 The complex geologic and geographic history of Central America has long intrigued researchers,

332 who have aimed to decipher how different features that act as barriers to or corridors for 
333 dispersal have affected the distribution and diversity of multiple taxa (Gutierrez-García \&

334 Vázquez-Dominguez, 2012; Bagley \& Johnson, 2014). Our results show a deep phylogenetic

335 structure of $H$. fleischmanni, which has differentiated as three well-supported clades, revealing

336 old divergence events dating back to the Pliocene and younger divergence events within clades

337 during the Pleistocene (Fig. 3). Additionally, our results agree with those of previous studies

338 showing H. fleischmanni to be paraphyletic with H. tatayoi (Guayasamin et al., 2008;

339 Castroviejo-Fisher et al., 2011; Delia, Bravo-Valencia \& Warkentin, 2017), and we found no

340 differences between the H. tatayoi and the H. fleischmanni samples within the South American

341 clade.

342 The Southern clade

343 The Southern clade encompasses samples from the Chocó and SAP regions, including the

344 species H. tatayoi from Venezuela. Samples ranging from Panama to Venezuela and Ecuador

345 grouped together, with no clear phylogenetic separation among them. However, haplotype

346 networks and spatial clustering analyses for coding genes allowed us to identify a partition on

347 both sides of the Northern Andes (Supplementary Material S1 and Supplementary Fig. S3). The

348 lack of significant structure for the Southern clade is remarkable, considering that the geographic

349 distances between populations reach 1,600 km. In addition, the CPI and the Northern Andes,

350 which are widely recognized as speciation drivers for both highland and lowland species (Bagley

351 \& Johnson, 2014; Mendoza et al., 2015), do not seem to have exerted any effect on the genetic

352 structure of this clade. Notably, the genetic distance observed on both sides of the Northern

353 Andes (COI K2P $=1.9 \%$; Table S1.1) is lower than the distances reported for lowland species

354 with a higher dispersal capacity from similar localities, such as the hummingbird Amazilia

355 amabilis (COI K2P = 2.06\%, Mendoza et al., 2016). These results contrast with previous 
356 knowledge of the ecology of glassfrog species, which have been found to be characterized by site

357 fidelity (Valencia-Aguilar, Castro-Herrera \& Ramírez-Pinilla, 2012), low mobility and restricted

358 gene flow even at local scales (Delia, Bravo-Valencia \& McDiarmid, 2017; Robertson, Lips \&

359 Heist, 2008). However, most of the previous research on this frog has focused on calling males

360 and reproductive behavior (Delia, Bravo-Valencia, \& McDiarmid, 2017), while the dispersal

361 capability of females and tadpoles, which can have a significant impact on mtDNA genetic

362 structure, is still unknown. Thus, it is possible that the Chocó and SAP regions present adequate

363 conditions for tadpole dispersal, allowing range expansion. However, this hypothesis needs to be

364 evaluated based on additional demographic studies and a greater sample size per site.

365 Our results do not support our initial hypothesis that the species was originally from South

366 America and then dispersed through the Isthmus of Panama. Indeed, the Southern clade is rather

367 young, and the various populations it encompasses differentiated during the last million years

368 (middle Pleistocene). Our results show that this clade has experienced a recent population

369 expansion during the last 100,000-300,000 years, reaching a relatively final stable population

370 size, exhibiting a dispersal route from Central Panama to South America (Fig. 5). Based on the

371 genetic and phylogenetic results for this clade, we suggest that its dispersal towards South

372 America and on both sides of the Northern Andes occurred very recently, likely as a

373 consequence of climatic oscillations during glacial periods (Smith, Amei \& Kickla 2012). Under

374 this scenario, there has been insufficient time for effective genetic differentiation to occur, and

375 the phylogenetic reconstruction therefore failed to resolve the divergence detected in the spatial

376 analysis.

377 In particular, the lack of differentiation between sequences from east of Northern Andes (in the

378 Magdalena Valley) and H. tatayoi in Serranía del Perijá is remarkable: sequences were identical 
379 with extremely low divergence $\left(\mathrm{F}_{\mathrm{ST}}=0.0543\right.$, Table 1$)$, supporting a recent dispersal through the

380 Eastern Cordillera. In contrast, we detected a slight structure for the Ecuadorian record

381 (Geneland; Fig. 2b) based on a single specimen (QCAZ-22303). We acknowledge that a more

382 detailed genetic structure analysis of the Colombian and Ecuadorian populations is needed,

383 including samples from the southern departments in Colombia, and the use of additional genetic

384 markers (e.g., microsatellites or SNPs) is suggested.

The Northern clade

386

387

388

389

390

391

392

393

394

395

396

397

398

399

400
Unlike the Southern clade, the Northern clade shows significant genetic structure in four different lineages, ranging from western Chortis (Central America) to lowland forests in Veracruz and Guerrero (Mexico). One remarkable finding was the split between samples from either side of the MPJ fault system, where individuals separated by only $60 \mathrm{~km}$ exhibit great genetic distances ( $\mathrm{K} 2 \mathrm{P}=4.5 \%$ for all three genes, Table 1$)$, even reaching the limit of the $6 \%$ barcode gap for Neotropical amphibians in COI (5.2\% for COI, Table S1.2; Lyra et al., 2017). The calibration results showed that samples from these localities have been isolated since the Gelasian age (early Pleistocene; 2.19 Ma, HPD = 1.38-3.53). The MPJ fault system has been recognized as the main barrier to dispersal for multiple species ranging from the Maya to the Chortis blocks (Ornelas, Ruiz-Sánchez \& Sosa, 2010; Barrera-Guzman et al., 2012; Rovito et al., 2015;). Our results indeed support the hypothesis that MPJ has effectively acted as a barrier for H. fleischmanni dispersal.

On the other hand, the Geneland and phylogenetic results showed a more complex scenario, in agreement with the presence of three well-defined lineages within the Northern clade, one of which is located in the north of the SMB, another southward the SMB, and the last in the Maya 
401 block (Fig 2b). This genetic structure is very similar to that observed for the brush-finch

402 Arremon brunneinucha, distributed in humid montane forests (Navarro-Sigüenza et al., 2008).

403 Samples from the Gulf of Mexico and Pacific are clearly isolated by the highlands of the Sierra

404 Madre Oriental and the Sierra Madre Occidental (Fig. 1), indicating a divergence pattern that is 405 frequently detected for lowland species (Mulcahy, Morrill, \& Mendelson, 2006; Rivera-Ortíz et 406 al., 2016) and species groups (Streicher et al., 2014; Palacios et al., 2016).

407 Within this clade, we found that samples from SMB do not group as a single lineage but instead 408 display a paraphyletic position in relation to the lineage from the Maya region. These two 409 regions present the lowest K2P among all comparisons performed in this analysis, except for 410 samples separated by the WPI. Importantly, unlike the known impact of the WPI and CPI on 411 lowland species, the effect of the IT has mostly been defined in relation to montane species 412 (Bryson, García-Vázquez \& Riddle, 2011; Jiménez \& Ornelas, 2016), for which it represents a 413 dispersal-limiting barrier. Currently, the IT is occupied by dry, scrubby coastal plains that are 414 very different from the moist areas on either side (Rodriguez-Gómez, Gutierrez-Rodriguez \& 415 Ornelas, 2013), so one plausible explanation for this finding is that the dry forests along the IT 416 did not always act as a barrier to $H$. fleischmanni. Instead, considering that those clades were 417 likely isolated between 1.76 to $2.19 \mathrm{Ma}(\mathrm{HPD}=0.86-3.53)$, it is likely that the successive 418 glacial cycles during the Pleistocene could have enabled the montane forests to reach lower 419 elevations through the impact of climate change (Barber \& Klicka, 2010), thus creating a 420 temporal corridor and allowing the species to disperse through the region. Hence, for species like 421 H. fleischmanni, the IT probably acted as both a corridor and a barrier, which is supported by our 422 Bayesian spatiotemporal diffusion results (Fig. 5). 
424 Our results revealed a Central clade without any deep geographic structure expanding across the

425 HE and separated from the Southern clade around the end of the Pliocene ( 2.64 Ma). We did

426 not find any evidence suggesting differentiation between samples from the Chortis and

427 Chorotega regions, leading us to reject the hypothesis that the HE acted as a barrier. However,

428 we must consider the small sample sizes from Honduras and Nicaragua ( $\mathrm{n}=10$ samples), which

429 likely limits detailed structural evaluation for this region. Most phylogeographic studies

430 performed in the region known as nuclear Central America face similar problems, with limited or

431 null sampling from northern Honduras (Castoe et al., 2003; Crawford \& Smith, 2005; Mulcahy,

432 Morrill, \& Mendelson 2006) or sampling that is biased towards the dry forests of the Pacific

433 coast (Parkinson, Zamudio, \& Greene 2000; Hasbún et al., 2005; Vázquez-Miranda, Navarro-

434 Sigüenza \& Omland, 2009; Poelchau \& Hamrick, 2011), where H. fleischmanni has not been

435 recorded. Our Bayesian spatiotemporal diffusion results showed rapid dispersal from the

436 Chorotega to Chortis blocks, with no apparent impact on the genetic structure of these

437 populations (Fig. 5). Nevertheless, additional work is needed to confirm whether the main

438 geographic features present in this region have driven the dispersal of low-mobility species such

439 as H. fleischmanni in humid forests.

440 Phylogeographic patterns

441 The three main clades that we identified for $H$. fleischmanni show deep intraspecific divergence,

442 with genetic distance values (K2P) greater than 3\% (Table 2). Indeed, the landscape analysis,

443 Bayesian spatiotemporal diffusion analyses, and estimated divergence times revealed interesting

444 patterns that allowed us to reconstruct the historical biogeography of these frogs and identify the

445 impact of different geographic barriers on the genetic structure and phylogeographic patterns of

446 H. fleischmanni. Although the main phylogenetic topology and the three major clades were well 
447 supported in Bayesian analyses, the maximum likelihood phylogenetic reconstruction did not

448 resolve these relationships (see Supplementary Material).

449 The Bayesian spatiotemporal diffusion analysis did not support the hypothesis proposed by

450 Castroviejo-Fisher et al. (2014) of a South American origin and subsequent dispersal to Central

451 America. In contrast, $H$. fleischmanni appears to have originated in the region encompassing the

452 Chorotega and eastern Chortis elements. Interestingly, we found that H. fleischmanni has

453 undergone two dispersal events: one southwards towards the Chocó region and one northwards,

454 reaching the Maya region, followed by vicariance events driven by the effect of the Chortis

455 highlands and the Talamanca Range. Considering that all species that are closely related to $H$.

456 fleischmanni are endemic to South America and that the divergence times among the three clades

457 are similar (i.e., the isolation of the Northern clade occurred ca. 3.40 Ma (HPD = 2.25-4.56 Ma),

458 while that between the two other clades occurred 2.64 Ma $(\mathrm{HPD}=1.50-3.68))$, it is likely that

459 the MRCA ancestor of H. fleischmanni and H. carlesvilai was located in South America around

$4607.65 \mathrm{Ma}(\mathrm{CI}=5.93-9.63)$. Later, the ancestor of $H$. fleischmanni arrived in Central America

461 during the Pliocene, soon after the closure of the Isthmus of Panama (Montes et al., 2015),

462 whereas the current South American populations are descendants of a second migration from

463 Central to South America. Accordingly, the dispersal-vicariance events among the main clades

464 potentially occurred simultaneously or over a very short time, which might explain why the

465 position of the clades and their internal structure were not consistent between the Bayesian and

466 maximum likelihood approaches.

467 Regarding the vicariance events for the Central and Southern clades, multiple elements need to

468 be revised. The samples from each cluster that are geographically closest are located on opposite 469 sides of the Talamanca Cordillera in the Chorotega block. The time of divergence of the MRCA 
470 for these clades (3.28 Ma, HPD $=1.59-3.86)$ coincides with the estimated age of the intervening

471 mountains (1-2 Ma; Denyer, Alvarado \& Aguilar, 2000; Marshall et al., 2003), which are

472 recognized as a main driver of speciation (Savage, 2002). The time of divergence also coincides

473 with the rise of the sea level during the mid-late Pliocene $(\sim 3.5-3 \mathrm{Ma})$, which generated a

474 seaway, likely reinforcing the WPI break and therefore acting as a barrier across the Pacific

475 region (Cronin \& Dowsett, 1996; Bagley, Hickerson \& Johnson, 2018). Hence, the central

476 mountain ranges on Costa Rica and Panama and the eustatic sea levels around the WPI might

477 have increased divergence, as documented for multiple spatial divergence patterns of amphibian

478 species (Crawford, Bermingham \& Polanía-S, 2007; Wang, Crawford \& Bermingham, 2008;

479 Bagley, Hickerson \& Johnson, 2018).

480 The isolation of the Northern clade from the other two does not entirely correspond to our 481 hypothesis of geographical barriers. Populations from both the Northern and Central clades are 482 distributed throughout the Chortis block, indicating that the MPJ fault system was not the main 483 driver of divergence between clades. On the other hand, our structure (Geneland) results suggest 484 a frontier at the center of the Chortis block, near northeastern Honduras (Fig. 2b). Similar 485 divergence patterns have been observed between two water-dependent subspecies of Caiman 486 crocodilus (Venegas-Anaya et al., 2008), in agreement with the eastern limit of the Chortis 487 highlands (Morrone, 2014; Townsend, 2014). Here, the complex topography resulting from 488 multiple volcanic activities along the Chortis highlands during the last $2 \mathrm{Ma}$ and the presence of 489 dry habitats in the Pacific region (Savage, 2002) may have isolated the H. fleischmanni 490 populations during the late Pliocene. This hypothesis is in agreement with the high species 491 endemism recognized for the region (Anderson et al., 2010; Townsend et al., 2012), in which 
492 intensive study is required to evaluate the underestimated regional taxonomic diversity

493 (Townsend \& Wilson, 2016).

494 Taxonomic implications

495 Previous studies have suggested that H. fleischmanni is a paraphyletic species in relation to its

496 sister species H. tatayoi (Castroviejo-Fisher et al., 2011; Delia, Bravo-Valencia \& Warkentin,

497 2017). Here, we confirm the paraphyly of the species, as the H. tatayoi samples are grouped

498 within the Southern clade, lacking significant genetic differences from the western Andes

499 samples. Furthermore, our overall Bayesian topology agrees with the results obtained by Delia,

500 Bravo-Valencia \& Warkentin (2017) for $12 \mathrm{~S}$ sequences. We identified three main isolated

501 lineages with large genetic distances that likely include cryptic diversity within Central America.

502 To confirm the existence of cryptic — and potential candidate — species, different lines of

503 evidence must be obtained; in fact, we are conducting a follow-up study of the integrative

504 taxonomy of this species complex that includes genetic, morphologic and acoustic data

505 (Mendoza et al., in prep) to describe lineage divergence and determine the identities and

506 geographic distributions of all valid species (Padial et al., 2014).

\section{Conclusions}

508 We have conducted the most comprehensive analysis of genetic variation and divergence within H. fleischmanni to date, producing one of the few phylogenetic and phylogeographic studies for

510 glassfrogs, with the exception of a few studies from Guyana (Castroviejo-Fisher et al., 2011;

511 Jowers et al., 2015), and this is the first such study of a Central American species. Moreover, our

512 results aided in the successful reconstruction of the historical biogeography of these frogs and 513 dispersal and vicariance events during the history $H$. fleischmanni lineages, revealing a higher 
514 complexity for the species than expected, especially for the Northern lineage, in which

515 significant population structure was found. Indeed, our results support the Talamanca range, the

516 MPJ fault system, and the Chortis highlands as significant factors exerting effects on the

517 dispersal of lowland amphibians during the late Pliocene and early Pleistocene. Additionally, we

518 suggest that the IT acted as both a corridor and a barrier for H. fleischmanni during the early

519 Pleistocene, while the HE and the Andes Range did not act as significant barriers. The

520 complementary use of phylogenetic and landscape analyses allowed us to perform an adequate

521 evaluation of dispersal patterns and potential barriers within this region; hence, our approach can

522 be applied in biogeographic and phylogeographic studies of different taxa.

\section{Acknowledgments}

524 We sincerely thank the following researchers and institutions for their kind contributions of

525 tissue samples: David Wake from the Museum of Vertebrate Zoology (Berkeley, USA), Juan M.

526 Daza from Museo de la Universidad de Antioquia (Colombia), Fernando Rojas-Runjaic from

527 Museo de Historia Natural La Salle (Venezuela), Beatriz Alvarez from Museo Nacional de

528 Ciencias Naturales (CSIC, España), María Estefanía López and Andres M. Cuervo from

529 Colección de Tejidos of Instituto Alexander von Humboldt (Colombia), Adrian Nieto from

530 Museo de Zoología de la Facultad de Ciencias (UNAM, México), Jhon Tailor Rengifo from

531 Universidad Tecnológica del Chocó (Colombia), Carlos R. Vásquez-Almazán from Universidad

532 de San Carlos de Guatemala (Guatemala), Colección de Docencia (Universidad del Valle,

533 Colombia), and Josiah Townsend from Indiana University of Pennsylvania. We also thank Aldo

534 Lopez, Mirna G. Garcia, Angel F. Soto Omar Becerra, Itzue Caviendes-Solis, Angel I. Contreras,

535 Nelson Martín Cerón de la Luz, Abigail Mora-Reyes, Rene Murrieta-Galindo, Hibraim Pérez-

536 Mendoza, Alejandro Rodriguez, Jose Criollo, Eliana Barona, Oscar Cuellar and Jonard David 
537 Echavarria-Renteria for their keen assistance in collecting samples and Mailyn A. Gonzalez,

538 Eduardo Tovar Luque, Andrea Jiménez, Martin García and Laura Cifuentes for allowing the use

539 of laboratory facilities and their invaluable support in laboratory procedures. An earlier version

540 of the manuscript was improved due to the kind suggestions of Victoria Sosa, Juan Manuel

541 Guayasamin, Cristiano Vernesi and one anonymous reviewer. This paper constitutes a partial

542 fulfillment of the Graduate Program in Biological Sciences (Posgrado en Ciencias Biológicas) of

543 the Universidad Nacional Autónoma de México (UNAM) for AMM.

\section{Funding statement}

545 AMM was supported by CONACYT fellowship 416922. This project was supported by PAPIIT-

546 DGAPA (UNAM) project IN203617 and the Rufford Foundation (Rufford Small Grant reference 547 18423-1).

\section{References}

549 Anderson DL, House P, Hyman RE, Steiner R, Hawkins HR, Thorn S, Rey MJ, Espinal MR, 550 Marineros LE. 2010. Rediscovery of the Honduran Emerald Amazilia luciae in western 551 Honduras: insights on the distribution, ecology, and conservation of a 'Critically Endangered' 552 hummingbird. Bird Conservation International 20(3):255-262

553 Arbeláez-Cortés E, Nyári ÁS, Navarro-Sigüenza AG, 2010. The differential effect of lowlands 554 on the phylogeographic pattern of a Mesoamerican montane species (Lepidocolaptes affinis, 555 Aves: Furnariidae). Molecular Phylogenetics and Evolution 57(2):658-668

556 Bagley JC, Johnson JB. 2014. Phylogeography and biogeography of the lower Central American

557 Neotropics: diversification between two continents and between two seas. Biological Reviews 558 89(4):767-790

559 Bagley JC, Hickerson MJ, Johnson JB. 2018 Testing hypotheses of diversification in 560 Panamanian frogs and freshwater fishes using hierarchical approximate Bayesian computation 561 with model averaging. PeerJ Preprints 6, e26623v1

562 https://doi.org/10.7287/peerj.preprints.26623v1 
563 Barber BR, Klicka J. 2010. Two pulses of diversification across the Isthmus of Tehuantepec in a 564 montane Mexican bird fauna. Proceedings of the Royal Society of London B: Biological 565 Sciences, 277:2675-2681.

566 Barrera-Guzmán AO, Milá B, Sánchez-González LA, Navarro-Sigüenza AG. 2012. Speciation in 567 an avian complex endemic to the mountains of Middle America (Ergaticus, ves: Parulidae).

568 Molecular phylogenetics and Evolution 62(3):907-920

569 Barrera-Rodríguez M. 2000. Estudio Anatómico de cuatro especies de ranitas de cristal del 570 género Hyalinobatrachium Ruíz and Lynch 1991 grupo fleischmanni (Amphibia: Anura: 571 Centrolenidae). Revista de la Academia Colombiana de Ciencias Exactas, Físicas y Naturales $572 \quad 23: 245-260$.

573 Beebee TJC, 2005. Conservation genetics of amphibians. Heredity 95(6):423-427.

574 Bielejec F, Baele G, Vrancken B, Suchard MA, Rambaut A, Lemey P. 2016. SpreaD3:

575 interactive visualisation of spatiotemporal history and trait evolutionary processes. Molecular 576 Biology and Evolution, 33(8):2167-2169

577 Bryson RW, García-Vázquez UO, Riddle BR. 2011. Phylogeography of Middle American 578 gophersnakes: mixed responses to biogeographical barriers across the Mexican Transition Zone. 579 Journal of Biogeography 38(8):1570-1584.

580 Cadena CD, Klicka J, Ricklefs RE. 2007. Evolutionary differentiation in the Neotropical 581 montane region: molecular phylogenetics and phylogeography of Buarremon brush-finches 582 (Aves-Emberizidae). Molecular Phylogenetics and Evolution 44(3):993-1016

583 Castoe TA, Chippindale PT, Campbell JA, Ammerman LK, Parkinson CL. 2003. Molecular 584 systematic of the middle American jumping pitvipers (genus Atropoides) and phylogeography of 585 the Atropoides nummifer complex. Herpetologica 59(3):421-432

586 Castroviejo-Fisher S, Ayarzagüena J, Vila C. 2007. A new species of Hyalinobatrachium 587 (Centrolenidae: Anura) from Serrania de Perijá, Venezuela. Zootaxa 1441(1):51-62

588 Castroviejo-Fisher S, Vila C, Ayarzagueena J, Blanc M, Ernst R. 2011. Species diversity of 589 Hyalinobatrachium glassfrogs (Amphibia: Centrolenidae) from the Guiana Shield, with the 590 description of two new species. Zootaxa 3132:1-55

591 Castroviejo-Fisher S, Guayasamin JM, Gonzalez-Voyer A, Vila C. 2014. Neotropical

592 diversification seen through glassfrogs. Journal of Biogeography 41(1):66-80

593 Cavender-Bares J, González-Rodríguez A, Pahlich A, Koehler K, Deacon N. 2011.

594 Phylogeography and climatic niche evolution in live oaks (Quercus series Virentes) from the 595 tropics to the temperate zone. Journal of Biogeography 38(5):962-981 
596 Cavers S, Navarro C, Lowe AJ, 2003. Chloroplast DNA phylogeography reveals colonization 597 history of a Neotropical tree, Cedrela odorata L., in Mesoamerica. Molecular Ecology 598 12(6):1451-1460.

599 Cox CB, Ladle R, Moore PD. 2016. Biogeography: an ecological and evolutionary approach. 600 Blackwell Science Ltd., Oxford.

601 Crawford AJ, Smith EN. 2005. Cenozoic biogeography and evolution in direct-developing frogs 602 of Central America (Leptodactylidae: Eleutherodactylus) as inferred from a phylogenetic 603 analysis of nuclear and mitochondrial genes. Molecular phylogenetics and evolution, 35(3):536604555.

605 Crawford AJ, Bermingham E, Polanía-S C. 2007. The role of tropical dry forest as a long-term 606 barrier to dispersal: a comparative phylogeographical analysis of dry forest tolerant and 607 intolerant frogs Molecular Ecology 16(22):4789-4807

608 Cronin TM, Dowsett HJ. 1996. Biotic and oceanographic response to the Pliocene closing of the 609 Central American Isthmus. In: Jackson, JBC, Budd AF, Coates A, eds. Evolution and 610 environment in tropical America. The University of Chicago Press, Chicago, 76-104.

611 Cruz FK, Urgiles VL, Sánchez-Nivicela JC, Siddons DC, Cisneros-Heredia D. 2017.

612 Southernmost records of Hyalinobatrachium fleischmanni (Anura: Centrolenidae). Check List 613 13(4):67-70.

614 Delia J, Cisneros-Heredia DF, Whitney J, Murrieta-Galindo R. 2010. Observations on the 615 reproductive behavior of a Neotropical glassfrog, Hyalinobatrachium fleischmanni (Anura:

616 Centrolenidae). South American Journal of Herpetology 5(1):1-12

617 Delia J, Bravo-Valencia L, McDiarmid RW. 2017. Notes on paternal behavior in 618 Hyalinobatrachium glassfrogs (Anura: Centrolenidae). Phyllomedusa 16(1):101-107.

619 Delia J, Bravo-Valencia L, Warkentin KM. 2017. Patterns of parental care in Neotropical 620 glassfrogs: fieldwork alters hypotheses of sex-role evolution. Journal of evolutionary biology $62130(5): 898-914$.

622 Denyer P, Alvarado GE, Aguilar T. 2000. Historia Geológica. in: P. Denyer and S. Kussmaul 623 (Eds.), Geología de Costa Rica. Editorial Tecnológica de Costa Rica, San José, pp. 155-167.

624 Drummond AJ, Rambaut A, Shapiro B, Pybus OG. 2005. Bayesian coalescent inference of past 625 population dynamics from molecular sequences. Molecular biology and evolution, 22(5):11856261192

627 Drummond AJ, Rambaut A. 2007. BEAST: Bayesian evolutionary analysis by sampling trees. 628 BMC evolutionary biology, 7(1):214. 
629 Dudoit, A. A., Iacchei, M., Coleman, R. R., Gaither, M. R., Browne, W. E., Bowen, B. W., \& 630 Toonen, R. J. (2018). The little shrimp that could: phylogeography of the circumtropical 631 Stenopus hispidus (Crustacea: Decapoda), reveals divergent Atlantic and Pacific lineages. PeerJ, 6326, e4409.

633 Eizirik E, Kim JH, Menotti-Raymond M, Crawshaw Jr. PG, O'Brien SJ, Johnson WE. 2001. 634 Phylogeography, population history and conservation genetics of jaguars (Panthera onca, 635 Mammalia, Felidae). Molecular Ecology 10(1):65-79

636 García-Moreno J, Navarro-Sigüenza AG, Peterson AT, Sánchez-González LA. 2004. Genetic 637 variation coincides with geographic structure in the common bush-tanager (Chlorospingus 638 ophthalmicus) complex from Mexico. Molecular Phylogenetics and Evolution 33(1):186-196.

639 Gehara M, Crawford AJ, Orrico VGD, Rodríguez A, Lötters S, Fouquet A, Barrientos LS, 640 Brusquetti F, De La Riva I, Ernst R, Urrutia GG, Glaw F, Guayasamin JM, Hölting M, Jansen 641 M, Kok PJR, Kwet A, Lingnau R, Lyra M, Moravec J, Pombal JP, Rojas-Runjaic FJM, Schulze 642 A, Señaris JC, Solé M, Rodrigues MT, Twomey E, Haddad CFB, Vences M, Köhler J. 2014. 643 High levels of diversity uncovered in a widespread nominal taxon: continental phylogeography 644 of the neotropical tree frog Dendropsophus minutus. PLOS ONE 9:e103958

645 Goudet J, Jombart T. 2015. hierfstat: estimation and tests of hierarchical F-statistics. R package 646 version $0.04-22$.

647 Guayasamin JM, Castroviejo-Fisher S, Ayarzagüena J, Trueb L, Vilà C. 2008. Phylogenetic 648 relationships of glassfrogs (Centrolenidae) based on mitochondrial and nuclear genes. Molecular 649 Phylogenetics and Evolution 48(2):574-595

650 Guayasamin JM, Castroviejo-Fisher S, Trueb L, Ayarzagüena J, Rada M, Vilá C. 2009. 651 Phylogenetic systematics of Glassfrogs (Amphibia: Centrolenidae) and their sister taxon 652 Allophryne ruthveni. Zootaxa 2100: -97.

653 Guillot G, Mortier F, Estoup A. 2005. GENELAND: a computer package for landscape genetics. 654 Molecular ecology notes 5(3):712-715.

655 Gutiérrez-García TA, Vázquez-Domínguez E. 2013. Consensus between genes and stones in the 656 biogeographic and evolutionary history of Central America. Quaternary Research 79(3):311-324

657 Hasbún CR, Gómez A, Khöler GG, Lunt DH. 2005. MitochondrialDNA phylogeography of the 658 Mesoamerican spiny-tailed lizards (Ctenosaura quinquecarinata complex): historical 659 biogeography, species status and conservation. Molecular Ecology 14(10):3095-3107

660 Hauswaldt JS, Ludewig AK, Vences M, Pröhl H. 2011. Widespread co-occurrence of divergent 661 mitochondrial haplotype lineages in a Central American species of poison frog (Oophaga 662 pumilio). Journal of Biogeography, 38(4):711-726 
663 Iturralde-Vinent MA. 2006. Meso-Cenozoic Caribbean paleogeography: implications for the 664 historical biogeography of the region. International Geology Review,48(9):791-827

665 Jiménez RA, Ornelas JF. 2016. Historical and current introgression in a Mesoamerican

666 hummingbird species complex: a biogeographic perspective. PeerJ 4:e1556

667 Jombart T, Devillard S, Dufour A-B, Pontier D. 2008a. Revealing cryptic spatial patterns in 668 genetic variability by a new multivariate method. Heredity 101(1):92-103

669 Jombart T, 2008b. adegenet: a R package for the multivariate analysis of genetic markers.

670 Bioinformatics 24(11):1403-1405

671 Jombart T, Devillard S, Balloux F. 2010. Discriminant analysis of principal components: a new

672 method for the analysis of genetically structured populations. BMC genetics 11(1):94

673 Jowers MJ, Lehtinen RM, Downie RJ, Georgiadis AP, Murphy JC. 2015. Molecular

674 phylogenetics of the glass frog Hyalinobatrachium orientale (Anura: Centrolenidae): evidence

675 for Pliocene connections between mainland Venezuela and the island of Tobago. Mitochondrial

676 DNA 26(4):613-618

677 Kodandaramaiah U. 2011. Tectonic calibrations in molecular dating. Current Zoology 57(1):116678124.

679 Lait, L. A., \& Hebert, P. D. (2018). Phylogeographic structure in three North American tent 680 caterpillar species (Lepidoptera: Lasiocampidae): Malacosoma americana, M. californica, and 681 M. disstria. PeerJ, 6, e4479.

682 Lanfear R, Frandsen P., Wright AM, Senfeld T, Calcott B. 2016. PartitionFinder 2: new methods 683 for selecting partitioned models of evolution for molecular and morphological phylogenetic 684 analyses. Molecular Biology and Evolution, 34(3):772-773

685 Lemey P, Rambaut A, Welch JJ, Suchard MA. 2010. Phylogeography takes a relaxed random 686 walk in continuous space and time. Molecular biology and evolution 27(8):1877-1885.

687 Lyra,ML, Haddad CF, Azeredo-Espin AML. 2017. Meeting the challenge of DNA barcoding 688 Neotropical amphibians: polymerase chain reaction optimization and new COI primers. 689 Molecular ecology resources 17(5):966-980

690 Marshall LG, Webb SD, Sepkoski JJ, Raup DM. 1982. Mammalian evolution and the great 691 American interchange. Science 215(4538):1351-1357

692 Marshall JS, Idleman BD, Gardner TW, Fisher DM. 2003. Landscape evolution within a 693 retreating volcanic arc, Costa Rica, Central America. Geology 31(5):419-422 
694 Marshall JS. 2007. The geomorphology and physiographic provinces of Central America.

695 Central America: geology, resources and hazards, 1:75-121.

696 Mendoza ÁM, Arita HT. 2014. Priority setting by sites and by species using rarity, richness and 697 phylogenetic diversity: the case of neotropical glassfrogs (Anura: Centrolenidae). Biodiversity 698 and Conservation 23(4):909-926

699 Mendoza ÁM, Ospina OE, Cárdenas-Henao H, García-R JC. 2015. A likelihood inference of 700 historical biogeography in the world's most diverse terrestrial vertebrate genus: Diversification

701 of direct-developing frogs (Craugastoridae: Pristimantis) across the Neotropics. Molecular 702 phylogenetics and evolution 85:50-58

703 Mendoza ÁM, Torres MF, Paz A, Trujillo-Arias N, López-Alvarez D, Sierra S, Forero F, 704 González MA. 2016. Cryptic diversity revealed by DNA barcoding in Colombian illegally traded 705 bird species. Molecular ecology resources 16(4):862-873

706 Montes C, Cardona A, McFadden R, Morón SE, Silva CA, Restrepo-Moreno S, Ramírez DA, 707 Hoyos N, Wilson J, Farris D, Bayona GA, Jaramillo CA, Valencia V, Bryan J, Flores JA, 708 Bayona GA. 2012a. Evidence for middle Eocene and younger land emergence in central 709 Panama: implications for Isthmus closure. Bulletin, 124(5-6):780-799

710 Montes C, Bayona G, Cardona A, Buchs DM, Silva CA, Morón S, Hoyos N, Ramírez DA, 711 Jaramillo CA, Valencia V. 2012b. Arc-continent collision and orocline formation: Closing of the 712 Central American seaway. Journal of Geophysical Research: Solid Earth, 117(B4)

713 Montes C, Cardona A, Jaramillo C, Pardo A, Silva JC, Valencia V, Ayala C, Pérez-Angel LC, 714 Rodriguez-Parra LA, Ramirez V, Niño H. 2015. Middle Miocene closure of the Central 715 American seaway. Science 348(6231):226-229

716 Morrone JJ. 2014. Biogeographical regionalisation of the Neotropical region. Zootaxa 3782(1):1$717 \quad 110$

718 Mulcahy DG, Morrill BH, Mendelson JRI. 2006. Historical biogeography of lowland species of 719 toads (Bufo) across the Trans-Mexican Neovolcanic Belt and the Isthmus of Tehuantepec.

720 Journal of Biogeography 33(11):1889-1904

721 Myers N, Mittermeier RA, Mittermeier CG, Da Fonseca GA, Kent J. 2000. Biodiversity hotspots 722 for conservation priorities. Nature 403(6772):853-858

723 Navarro-Sigüenza AG, Peterson AT, Nyari A, García-Deras GM, García-Moreno J. 2008.

724 Phylogeography of the Buarremon brush-finch complex (Aves, Emberizidae) in Mesoamerica.

725 Molecular phylogenetics and evolution 47(1):21-35 
726 Noss RF. 1991. Landscape connectivity: different functions at different scales. Landscape

727 linkages and biodiversity. Island Press, Washington DC.

728 Ordóñez-Garza N, Matson JO, Strauss RE, Bradley RD, Salazar-Bravo J. 2010. Patterns of

729 phenotypic and genetic variation in three species of endemic Mesoamerican Peromyscus

730 (Rodentia: Cricetidae). Journal of Mammalogy 91(4):848-859

731 Ornelas JF, Ruiz-Sánchez E, Sosa V, 2010. Phylogeography of Podocarpus matudae

732 (Podocarpaceae): pre-Quaternary relicts in northern Mesoamerican cloud forests. Journal of

733 Biogeography 37(12):2384-2396.

734 Padial JM, Miralles A, De la Riva I, Vences M, 2010. The integrative future of taxonomy.

735 Frontiers in zoology, 7(1):16

736 Palacios M, Voelker G, Rodriguez LA, Mateos M, Tobler M. 2016. Phylogenetic analyses of the 737 subgenus Mollienesia (Poecilia, Poeciliidae, Teleostei) reveal taxonomic inconsistencies, cryptic

738 biodiversity, and spatio-temporal aspects of diversification in Middle America. Molecular 739 phylogenetics and evolution 103:230-244.

740 Paradis E, Claude J, Strimmer K. 2004. APE: analyses of phylogenetics and evolution in R

741 language. Bioinformatics, 20:289-290.

742 Parkinson CL, Zamudio KR, Greene HW. 2000. Phylogeography of the pitviper clade

743 Agkistrodon: historical ecology, species status, and conservation of cantils. Molecular Ecology

744 9(4):411-420

745 Pérez-Consuegra SG, Vázquez-Domínguez E. 2017. Intricate evolutionary histories in montane

746 species: a phylogenetic window into craniodental discrimination in the Peromyscus mexicanus

747 species group (Mammalia: Rodentia: Cricetidae). Journal of Zoological Systematics and

748 Evolutionary Research 55(1):57-72

749 Poelchau MF, Hamrick JL. 2011. Comparative phylogeography of three common Neotropical

750 tree species. Journal of Biogeography 40(4):618-631

751 Rambaut A, Drummond AJ, Xie D, Baele G and Suchard MA. 2018. Posterior summarisation in 752 Bayesian phylogenetics using Tracer 1.7. Systematic Biology 67(5): 901-90

753 Ramírez DA, Foster DA, Min K, Montes C, Cardona A, Sadove G. 2016. Exhumation of the 754 Panama basement complex and basins: Implications for the closure of the Central American 755 seaway. Geochemistry, Geophysics, Geosystems 17(5):1758-1777

756 Rivera-Ortíz FA, Solórzano S, Arizmendi MDC, Dávila-Aranda P, Oyama K. 2016. Genetic 757 Diversity and Structure of the Military Macaw (Ara militaris) in Mexico: Implications for 758 Conservation. Tropical Conservation Science 10:1-12 
759 Robertson JM, Lips KR, Heist EJ. 2008. Fine scale gene flow and individual movements among 760 subpopulations of Centrolene prosoblepon (Anura: Centrolenidae). Revista de biologia tropical, 761 56(1):13-26

762 Rodríguez-Gómez F, Gutiérrez-Rodríguez C, Ornelas JF. 2013. Genetic, phenotypic and 763 ecological divergence with gene flow at the Isthmus of Tehuantepec: the case of the

764

765

766

767

768

769

770

771

772

773

774

775

776

777

778

779

780

781

782

783

784

785

786

787

788

789

790

azure-crowned hummingbird (Amazilia cyanocephala). Journal of Biogeography, 40:1360-1373.

Ronquist F, Huelsenbeck JP. 2003. MRBAYES 3: Bayesian phylogenetic inference under mixed models. Bioinformatics 19(12):1572-1574.

Ronquist F, Sanmartín I, 2011. Phylogenetic methods in biogeography. Annual Review of Ecology, Evolution, and Systematics 42:441-464.

Rovito SM, Vásquez-Almazán CR, Papenfuss TJ, Parra-Olea G, Wake DB. 2015. Biogeography and evolution of Central American cloud forest salamanders (Caudata: Plethodontidae: Cryptotriton), with the description of a new species. Zoological Journal of the Linnean Society 175(1):150-166

Ruiz-Carranza PM, Lynch JD. 1991. Ranas Centrolenidae de Colombia I: Propuesta de una nueva clasificación genérica. Lozania 57:1-30.

Sambrook J, Russell DW. 2006. Purification of nucleic acids by extraction with phenol: chloroform. Cold Spring Harbor Protocols 2006(1):pdb-prot4455

Savage JM. 2002. The Amphibians and Reptiles of Costa Rica: A Herpetofauna between Two Continents, between Two Seas. University of Chicago press, Chicago.

Shapiro B, Rambaut A, Drummond AJ. 2005. Choosing appropriate substitution models for the phylogenetic analysis of protein-coding sequences. Molecular biology and evolution 23(1):7-9.

Smith SA, Stephens PR, Wiens JJ. 2005. Replicate patterns of species richness, historical biogeography, and phylogeny in Holarctic treefrogs. Evolution 59(11):2433-2450

Smith BT, Amei A, Klicka J. 2012. Evaluating the role of contracting and expanding rainforest in initiating cycles of speciation across the Isthmus of Panama. Proceedings of the Royal Society of London B: Biological Sciences, 279(1742):3520-3526.

Stamatakis A. 2006. RAxML-VI-HPC: maximum likelihood-based phylogenetic analyses with thousands of taxa and mixed models. Bioinformatics 22(21):2688-2690

Stehli FG, Webb SD. 1985. A kaleidoscope of plates, faunal and floral dispersals, and sea level changes, in: Stehli FG, Webb SD. eds. The great American biotic interchange. Springer, Boston, 3-16. 
791 Streicher JW, García-Vázquez UO, Ponce-Campos P, Flores-Villela O, Campbell JA, Smith EN,

792 2014. Evolutionary relationships amongst polymorphic direct-developing frogs in the

793 Craugastor rhodopis species group (Anura: Craugastoridae). Systematics and Biodiversity

794 12(1):1-22

795 Townsend JH, Wilson LD, Medina-Flores M, Aguilar-Urbina E, Atkinson BK, Cerrato-Mendoza

796 CA, Contreras-Castro A, Gray LN, Herrera-B. LA, Luque-Montes IR, McKewy-Mejía M,

797 Alionso Portillo-Avilez A, Stubbs AL, McKewy-Mejía, M. 2012. A premontane hotspot for

798 herpetological endemism on the windward side of Refugio de Vida Silvestre Texíguat,

799 Honduras. Salamandra 48(2):92-114.

800 Townsend JH, 2014. Characterizing the Chortís Block Biogeographic Province: Geological,

801 physiographic, and ecological associations and herpetofaunal diversity. Mesoamerican

802 Herpetology 1(2):204-252

803 Townsend JH, \& Wilson LD. 2016. Amphibians of the Cordillera Nombre de Dios, Honduras:

804 COI barcoding suggests underestimated taxonomic richness in a threatened endemic fauna.

805 Mesoamerican Herpetology, 3(4):910-927.

806 Valencia-Aguilar A, Castro-Herrera F, Ramírez-Pinilla MP. 2012. Microhabitats for oviposition

807 and male clutch attendance in Hyalinobatrachium aureoguttatum (Anura: Centrolenidae). Copeia

808 2012(4):722-731

809 Vázquez-Miranda H, Navarro-Sigüenza AG, Omland KE. 2009. Phylogeography of the rufous-

810 naped red (Camphylorhynchus rufinucha): Speciation and hybridization in Mesoamerica. The

811 Auk 126(4):765-778

812 Venegas-Anaya M, Crawford AJ, Escobedo-Galván AH, Sanjur OI, Densmore LD, Bermingham

813 E, 2008. Mitochondrial DNA phylogeography of Caiman crocodilus in Mesoamerica and South

814 America. Journal of Experimental Zoology Part A: Ecological and Integrative Physiology

815 309(10):614-627

816 Villa J, Valerio CE. 1982. Red, white and brown: preliminary observation on the color of the

817 centrolenid tadpole (Amphibia: Anura: Centrolenidae). Brenesia 1982(19/20): 1-16.

818 Wang IJ, Crawford AJ, Bermingham E. 2008. Phylogeography of the pygmy rain frog

819 (Pristimantis ridens) across the lowland wet forest of isthmian Central America. Molecular

820 phylogenetics and evolution 47(3):992-1004

821 Wiens JJ, Graham CH, Moen DS, Smith SA, Reeder TW. 2006. Evolutionary and ecological

822 causes of the latitudinal diversity gradient in hylid frogs: treefrog trees unearth the roots of high

823 tropical diversity. The American Naturalist 168(5):579-596 
824 Figure Captions

825 Fig. 1. Geographic distribution of H. fleischmanni samples. Main geological blocks, delimited by 826 geological barriers, are shown. Sample origins are indicated by black dots, while gray polygons

827 show the species distribution according to IUCN. SMB $=$ South Mexican block, SAP $=$ South

828 American Plate. The evaluated barriers are numbered as follows: $1=$ Isthmus of Tehuantepec, 2

829 = Motagua-Polochic-Jocotán fault system, 3= Hess Escarpment, $4=$ Talamanca Range, $5=$

830 Western Panama Isthmus, $6=$ Central Panama Isthmus, $7=$ Northern Andes and $8=$ Eastern 831 Cordillera.

832 Fig. 2. Results of the (a) Bayesian (Geneland) and (b-c) multivariate spatial analyses (sPCA) for 833 H. fleischmanni population clustering based on mtDNA sequences. For the sPCA analysis, the 834 color of each point in (b) is determined in the red-green-blue (RGB) system based on the score of 835 each individual on the first (translated to a red channel) and second axes (translated to green) of 836 the sPCA. The points of (c) represent the values of the two first sPCA components, and the 837 colors indicate the predicted clusters resulting from the hypothesized barriers.

838 Fig 3. Time-calibrated tree of $H$. fleischmanni unique haplotypes, inferred from BEAST based 839 on the combined ribosomal (16S) and protein-coding (COI, ND1) mitochondrial sequences, with 840 calibration on three nodes indicated by green bars (see Materials and Methods section for 841 details). Blue rectangles over key nodes indicate the 95\% highest posterior densities (HPD) of

842 the estimated times of divergence events (in Ma). Clade support is indicated by posterior BI 843 values in BEAST and MrBayes and by RAxML Bootstrap analysis and is presented in this order 844 separated by a slash. Asterisks at tips represent $H$. tatayoi samples included in the analysis. The 845 inner map shows the geographic locations of haplotype lineages. Each color in the map coincides 846 with the haplogroup obtained in the phylogenetic reconstruction. 
847 Fig. 4. Bayesian skyline plots for Northern (A) and Southern (B) clades generated through 848 phylogenetic reconstruction.

849 Fig. 5. Spatial projection of the Bayesian spatiotemporal diffusion analysis of H. fleischmanni 850 lineages for three time-points, based on the maximum clade credibility (MCC) tree estimated 851 with a "Relaxed Random Walk" model. Lines represent branches of the MCC tree; shaded areas 852 indicate the 95\%-HPD uncertainty for the ancestral branches; the shading gradient indicates 853 older (lighter) versus younger (darker) events; and dot color represents the ages of older nodes 854 (darker) and younger tips (lighter). 
Figure 1

Geographic distribution of $H$. fleischmanni samples

Geographic distribution of $\mathrm{H}$. fleischmanni samples. Main geological blocks, delimited by geological barriers, are shown. Sample origins are indicated by black dots, while gray polygons show the species distribution according to IUCN. SMB = South Mexican block, SAP = South American Plate. The evaluated barriers are numbered as follows: $1=$ Isthmus of Tehuantepec, 2 = Motagua-Polochic-Jocotán fault system, 3= Hess Escarpment, 4 = Talamanca Range, $5=$ Western Panama Isthmus, $6=$ Central Panama Isthmus, $7=$ Northern Andes and $8=$ Eastern Cordillera.

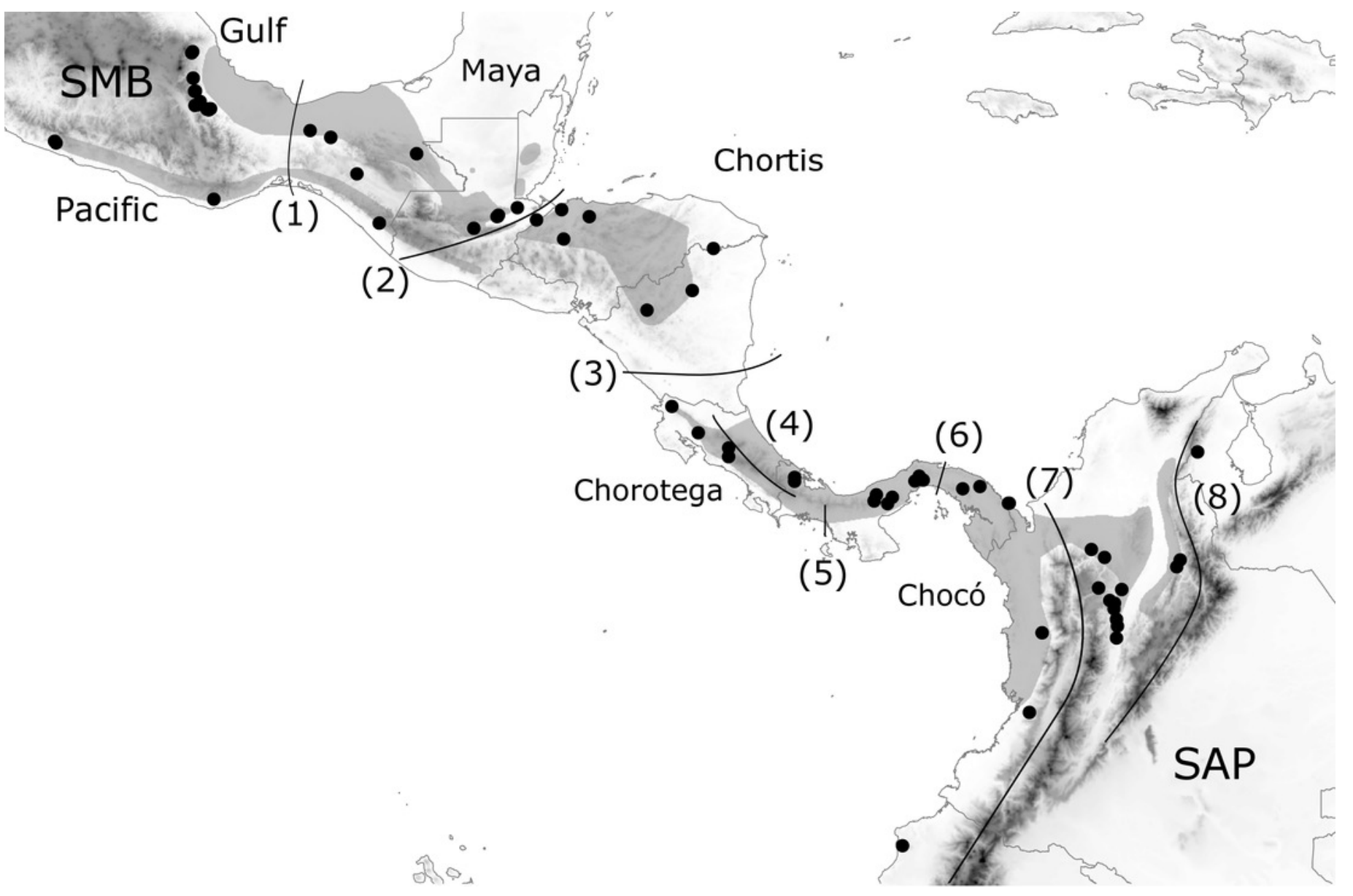




\section{Figure 2 (on next page)}

Results of the (a) Bayesian (Geneland) and (b-c) multivariate spatial analyses (sPCA) for H. fleischmanni population clustering based on mtDNA sequences

Results of the (a) Bayesian (Geneland) and (b-c) multivariate spatial analyses (sPCA) for $\mathrm{H}$. fleischmanni population clustering based on mtDNA sequences. For the SPCA analysis, the color of each point in (b) is determined in the red-green-blue (RGB) system based on the score of each individual on the first (translated to a red channel) and second axes (translated to green) of the SPCA. The points of (c) represent the values of the two first SPCA components, and the colors indicate the predicted clusters resulting from the hypothesized barriers. 


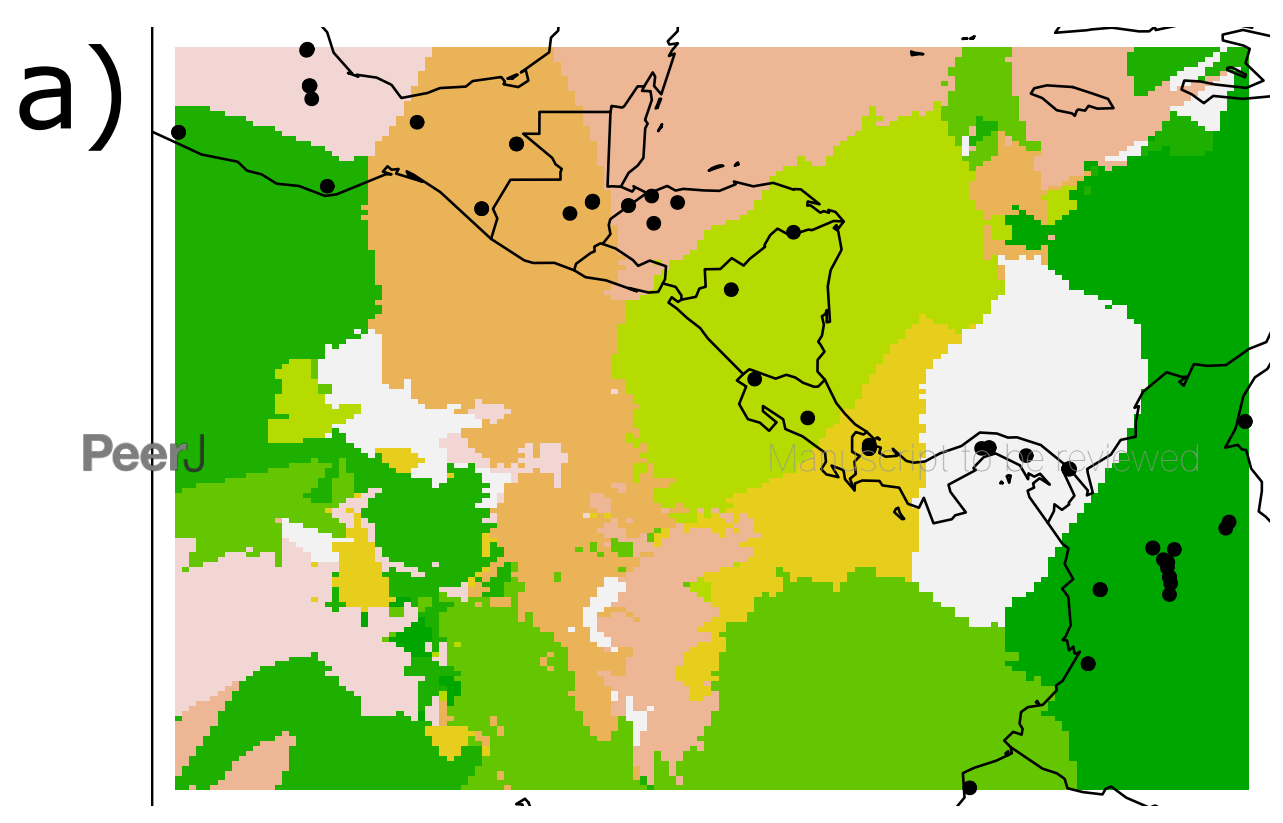

b)

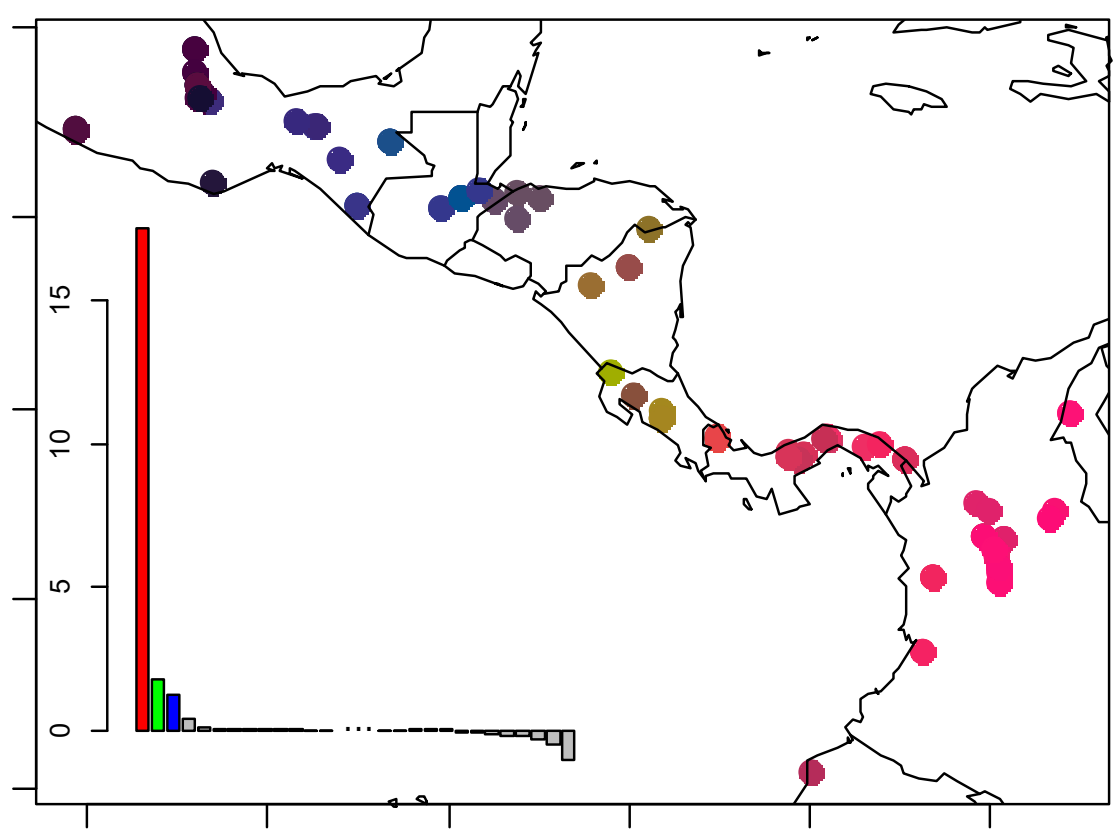

C)

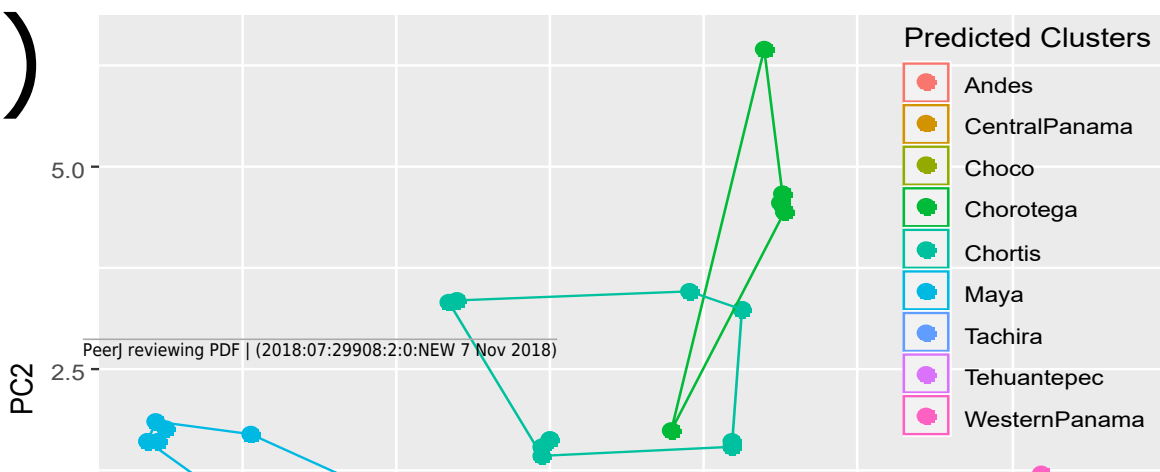

$0.0-$

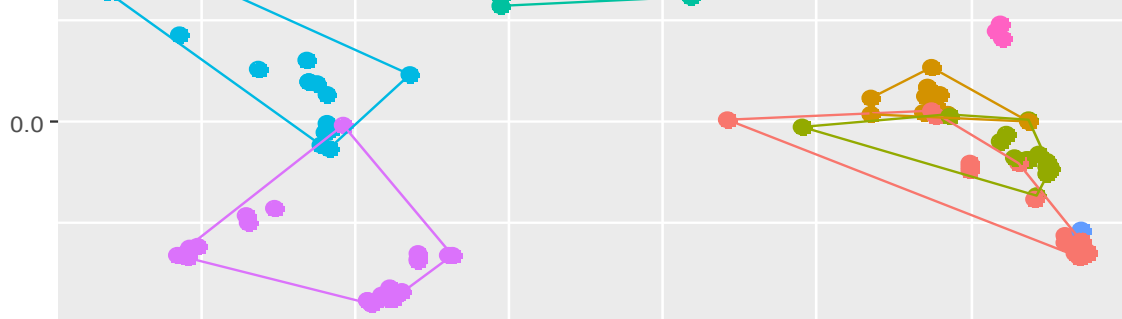




\section{Figure 3}

Time-calibrated tree of $H$. fleischmanni unique haplotypes

Time-calibrated tree of $\mathrm{H}$. fleischmanni unique haplotypes, inferred from BEAST based on the combined ribosomal (16S) and protein-coding (COI, ND1) mitochondrial sequences, with calibration on three nodes indicated by green bars (see Materials and Methods section for details). Blue rectangles over key nodes indicate the $95 \%$ highest posterior densities (HPD) of the estimated times of divergence events (in Ma). Clade support is indicated by posterior BI values in BEAST and MrBayes and by RAxML Bootstrap analysis and is presented in this order separated by a slash. Asterisks at tips represent $H$. tatayoi samples included in the analysis. The inner map shows the geographic locations of haplotype lineages. Each color in the map coincides with the haplogroup obtained in the phylogenetic reconstruction.

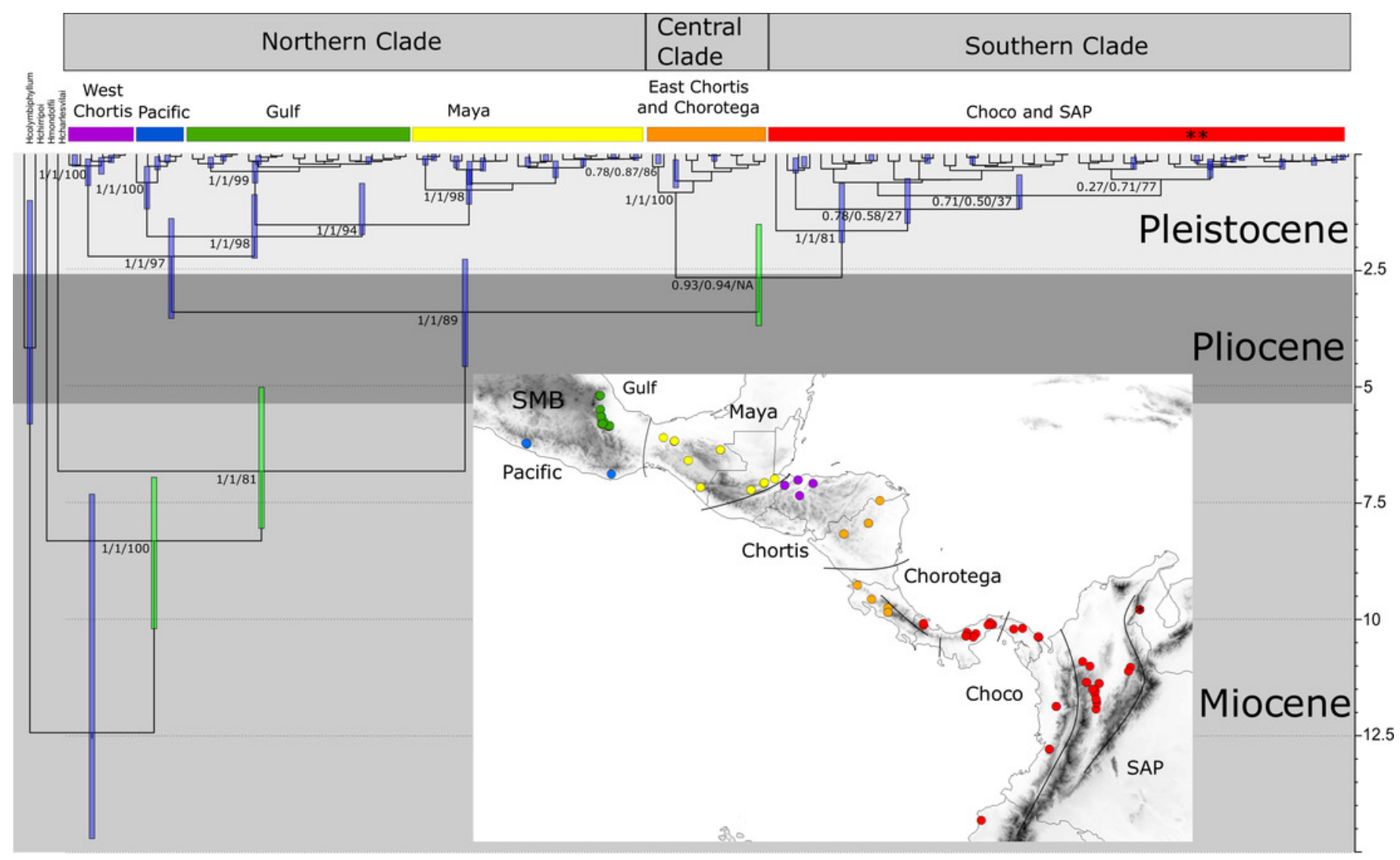


Figure 4 (on next page)

Bayesian skyline plots

Bayesian skyline plots for Northern (A) and Southern (B) clades generated through phylogenetic reconstruction 


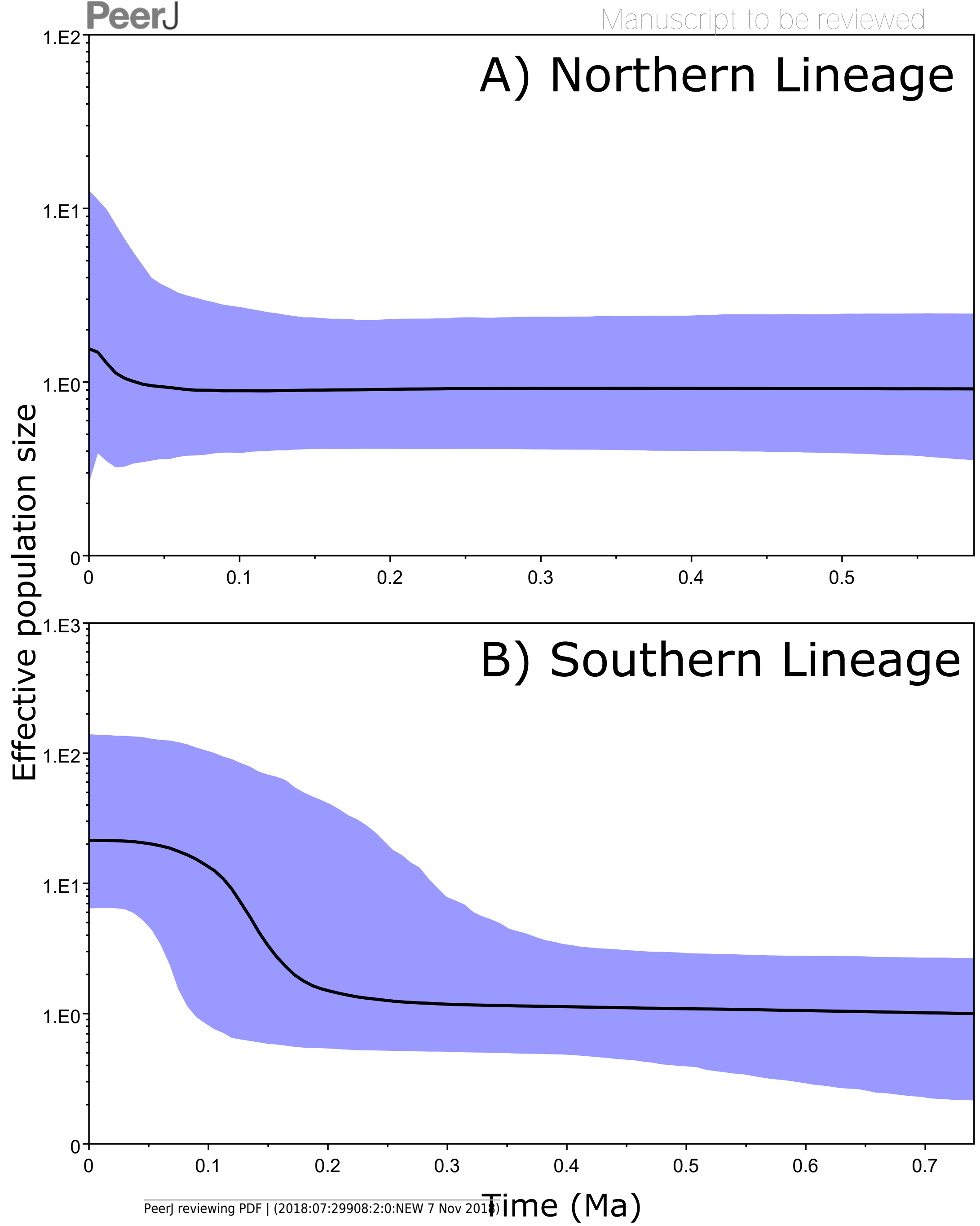


Figure $\mathbf{5}$ (on next page)

Spatial projection of the Bayesian spatiotemporal diffusion analysis of $H$. fleischmanni

Spatial projection of the Bayesian spatiotemporal diffusion analysis of $H$. fleischmanni

lineages for three time-points, based on the maximum clade credibility (MCC) tree estimated with a "Relaxed Random Walk" model. Lines represent branches of the MCC tree; shaded areas indicate the 95\%-HPD uncertainty for the ancestral branches; the shading gradient indicates older (lighter) versus younger (darker) events; and dot color represents the ages of older nodes (darker) and younger tips (lighter). 


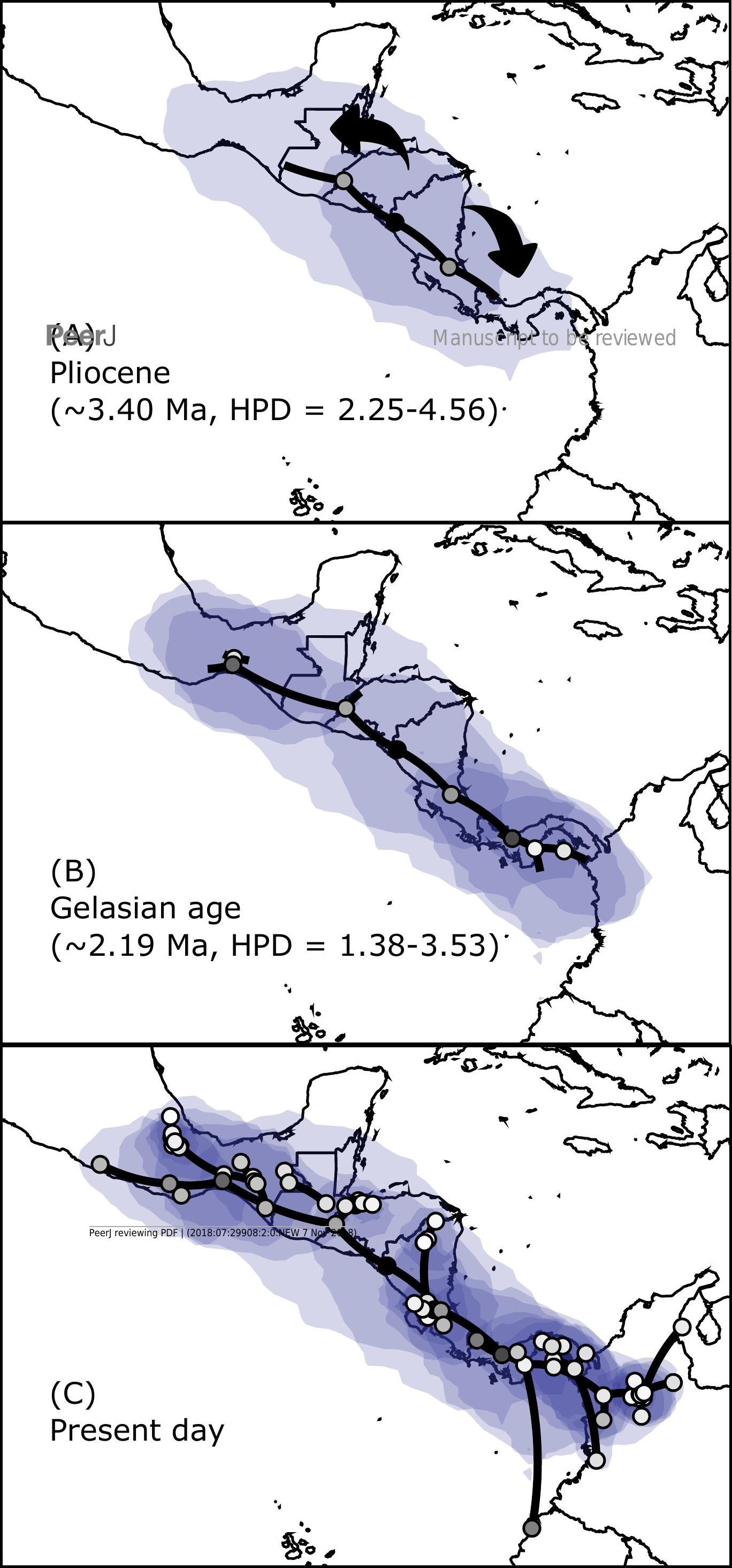




\section{Table $\mathbf{1}$ (on next page)}

Geographic barriers for Hyalinobatrachium fleischmanni

Detection of geographic barriers for Hyalinobatrachium fleischmanni by multiple approaches based on genetic structure. 1) Monte Carlo test of Nei's pairwise Fst based on 999 replicates , 2) agreement between the border maps generated with Geneland for the considered barriers, 3) degree of overlap between the two first sPCA components between adjacent populations, and 4) supported monophyletic lineages between distinct geographical regions. 
Table 1. Detection of geographic barriers for Hyalinobatrachium fleischmanni by multiple approaches based on genetic structure. 1) Monte Carlo test of Nei's pairwise Fst based on 999 replicates, 2) agreement between the border maps generated with Geneland for the considered barriers, 3) degree of overlap between the two first sPCA components between adjacent populations, and 4) supported monophyletic lineages between distinct geographical regions.

\begin{tabular}{|c|c|c|c|c|c|}
\hline Geographic barrier & Adjacent regions & Fst $(n=115)$ & $\begin{array}{l}\text { Geneland }(n= \\
60)\end{array}$ & sPCA $(n=115)$ & $\begin{array}{l}\text { Phylogeny }(n= \\
115)\end{array}$ \\
\hline Eastern Cordillera & $\begin{array}{l}\text { Serranía del Perijá / } \\
\text { Magdalena }\end{array}$ & 0.0543 & no agreement & complete overlap & not monophyletic \\
\hline Andes Range & Magdalena / Chocó & $0.3624 * *$ & no agreement & complete overlap & not monophyletic \\
\hline $\begin{array}{l}\text { Central Panama } \\
\text { Isthmus }\end{array}$ & Chocó / Central Panama & $0.3452 * *$ & no agreement & complete overlap & not monophyletic \\
\hline $\begin{array}{l}\text { Western Panama } \\
\text { Isthmus }\end{array}$ & $\begin{array}{l}\text { Central Panama / North } \\
\text { Talamanca Range }\end{array}$ & $0.7509 * * *$ & agreement & no overlap & not monophyletic \\
\hline Talamanca Range & $\begin{array}{l}\text { North Talamanca Range / } \\
\text { South Talamanca Range }\end{array}$ & $0.9071 * *$ & agreement & no overlap & monophyletic \\
\hline Hess Escarpment & $\begin{array}{l}\text { South Talamanca Range / } \\
\text { Chortis block }\end{array}$ & 0.4055 & no agreement & partial overlap & not monophyletic \\
\hline MPJ fault system & Chortis block / Maya block & $0.5262 * *$ & agreement & no overlap & monophyletic \\
\hline $\begin{array}{l}\text { Isthmus of } \\
\text { Tehuantepec }\end{array}$ & $\begin{array}{l}\text { Maya block / southern } \\
\text { Mexico block }\end{array}$ & $0.3733 * *$ & agreement & low overlap & not monophyletic \\
\hline
\end{tabular}




\section{Table 2 (on next page)}

\section{Mean K2P distances}

Mean K2P distances within and among populations (lower) for all tree mitochondrial genes and Nei's pairwise $F_{S T}$ indices per pair of populations (upper). Significance of $F_{S T}$ indices was estimated by a Monte Carlo test based on 999 permutations ( $\mathrm{ns}=$ non-significant; * $=\mathrm{p}$ value $<0.05 ; * *=p$-value $\leq 0.01 ; * * *=p$-value $\leq 0.001)$. 
1 Table 2. Mean K2P distances within and among populations (lower) for all tree mitochondrial genes and Nei's pairwise $\mathrm{F}_{\mathrm{ST}}$ indices per pair of 2 populations (upper). Significance of $\mathrm{F}_{\mathrm{ST}}$ indices was estimated by a Monte Carlo test based on 999 permutations (ns = non-significant; * $3=$ p-value $<0.05 ; * *=$ p-value $\leq 0.01 ; * * *=$ p-value $\leq 0.001)$.

\begin{tabular}{|l|c|c|c|c|c|c|c|c|}
\hline & $\begin{array}{c}\text { K2P Mean } \\
\text { Within distance }\end{array}$ & Chorotega & Chortis & Gulf & Maya & Pacific & $\begin{array}{c}\text { South } \\
\text { America }\end{array}$ & $\begin{array}{l}\text { Western } \\
\text { Panama }\end{array}$ \\
\hline Chorotega & 0.005 & 0 & $0.922^{* * *}$ & $0.845^{* * *}$ & $0.766^{* * *}$ & $0.879^{* * *}$ & $0.452^{* *}$ & $0.886^{* * *}$ \\
\hline Chortis & 0.004 & 0.048 & 0 & $0.801^{* * *}$ & $0.687^{* * *}$ & $0.876^{* * *}$ & $0.432^{* *}$ & $0.950^{* * *}$ \\
\hline Gulf & 0.005 & 0.046 & 0.04 & 0 & $0.545^{* *}$ & $0.635^{* * *}$ & $0.659^{* * *}$ & $0.815^{* *}$ \\
\hline Maya & 0.009 & 0.049 & 0.045 & 0.023 & 0 & $0.471^{* *}$ & $0.648^{* *}$ & $0.694^{* * *}$ \\
\hline Pacific & 0.004 & 0.047 & 0.036 & 0.022 & 0.023 & 0 & $0.413^{*}$ & $0.848^{* * *}$ \\
\hline South America & 0.009 & 0.035 & 0.057 & 0.046 & 0.051 & 0.043 & 0 & $0.138^{\text {ns }}$ \\
\hline Western Panama & 0.004 & 0.037 & 0.060 & 0.049 & 0.054 & 0.046 & 0.016 & 0 \\
\hline
\end{tabular}

